\title{
Prevalence and Characterization of Shiga Toxin-Producing and Enteropathogenic Escherichia coli in Shellfish-Harvesting Areas and Their Watersheds
}

\section{OPEN ACCESS}

Edited by: Anton F. Post

University of Rhode Island, USA

Reviewed by:

Erin Katherine Lipp,

University of Georgia, USA

Dale Leavitt,

Roger Williams University, USA

*Correspondence:

Michèle Gourmelon

michele.gourmelon@ifremer.fr

Specialty section:

This article was submitted to

Aquatic Microbiology,

a section of the journal

Frontiers in Microbiology

Received: 14 August 2015 Accepted: 16 November 2015 Published: 01 December 2015

Citation:

Balière C, Rincé A, Blanco J, Dahbi G, Harel J, Vogeleer P, Giard J-C, Mariani-Kurkdjian $P$ and Gourmelon M (2015) Prevalence and Characterization of Shiga

Toxin-Producing and

Enteropathogenic Escherichia coli in Shellfish-Harvesting Areas

and Their Watersheds.

Front. Microbiol. 6:1356. doi: 10.3389/fmicb.2015.01356

\section{Charlotte Balière ${ }^{1}$, Alain Rincé2, Jorge Blanco ${ }^{3}$, Ghizlane Dahbi 3 , Josée Harel Philippe Vogeleer ${ }^{4}$, Jean-Christophe Giard ${ }^{5}$, Patricia Mariani-Kurkdjian ${ }^{6,7,8}$ and Michèle Gourmelon ${ }^{*}$}

\begin{abstract}
1 Laboratoire Santé Environnement et Microbiologie, Unité Santé, Génétique et Microbiologie des Mollusques, Département Ressources Biologiques et Environnement, Ifremer, Plouzané, France, ${ }^{2}$ U2RM EA4655 Stress/Virulence,

Normandie-Université, University of Caen Normandy, Caen, France, ${ }^{3}$ Departamento de Microbioloxía e Parasitoloxía, Facultade de Veterinaria, Universidade de Santiago de Compostela, Lugo, Spain, ${ }^{4}$ Groupe de Recherche sur les Maladies Infectieuses du Porc, Département de Pathologie et Microbiologie, Faculté de Médecine Vétérinaire, Centre de Recherche d'Infectiologie Porcine et Avicole, Université de Montréal, Saint-Hyacinthe, QC, Canada, ${ }^{5}$ U2RM EA4655 Antibio-Résistance, Normandie-Université, University of Caen Normandy, Caen, France, ${ }^{6}$ Service de Microbiologie, CNR Associé Escherichia coli, AP-HP, Hôpital Robert-Debré, Paris, France, ${ }^{7}$ Infection, Antimicrobials, Modelling, Evolution, UMR 1137, INSERM, Paris, France, ${ }^{8}$ Infection, Antimicrobials, Modelling, Evolution, UMR 1137, Université Paris Diderot -

Sorbonne Paris Cité, Paris, France
\end{abstract}

During a 2-years study, the presence of Shiga-toxin producing Escherichia coli (STEC) and enteropathogenic E. coli (EPEC) was investigated in shellfish $(n=238)$, seawater $(n=12)$, and surface sediment $(n=39)$ collected from three French coastal shellfishharvesting areas and freshwaters $(n=216)$ in their watersheds. PCR detection of Shiga toxin- (stx1/stx2) and intimin- (eae) genes following enrichment from these samples revealed the presence of least one of the stx genes in $30.3 \%$ of shellfish batches, $85.9 \%$ of freshwater, $41.7 \%$ of seawater, and $28.2 \%$ of sediment samples, while the eae gene was observed in $74.8,100,100$, and $43.6 \%$ of shellfish batches, freshwater, seawater, and sediment samples, respectively. Twenty-eight STEC and 89 EPEC strains were isolated and analyzed in order to determine their serotype, phylogroup, and genetic relatedness and to evaluate the presence of the saa and ehxA genes encoding the STEC autoagglutinating adhesin and the enterohemolysin A, respectively. Finally, the ability to form biofilms and antimicrobial susceptibility were investigated for a selection of strains. Eighteen serotypes were identified among the STEC isolates and 57 among the EPEC isolates. A high diversity was observed within these strains, as 79 different PFGE patterns and 48 distinguishable sequence types were identified. Strains were found to belong mainly to phylogroups B1 and B2 and virulence was observed to be low as more than $85 \%$ of the strains possessed only st 1 , stx 2 , or eae genes. One STEC and several EPEC strains belonged to three of the five highly pathogenic serogroups (i.e., O26, O103, and 0145). The subset of strains tested for their capacity to form biofilms was mainly strongly to moderately adherent and 
more strains formed a strong biofilm at 18 than at $30^{\circ} \mathrm{C}$. Finally, more than $85 \%$ of analyzed strains were found to be sensitive to the 16 tested antibiotics. These data suggest the low risk of human infection by STEC if shellfish from these shellfishharvesting areas were consumed.

Keywords: STEC, EPEC, shellfish, water, MLST, PFGE, biofilms

\section{INTRODUCTION}

The microbiological quality of coastal environments can be impacted by urban and agricultural fecal wastes from watersheds. Moreover, shellfish can accumulate and concentrate pathogenic micro-organisms, such as Salmonella, pathogenic Escherichia coli (E. coli) and noroviruses present in surrounding waters by their filter-feeding activities (Potasman et al., 2002). This can lead to closures or downgrading of shellfish-harvesting areas and to outbreaks of food poisoning through consumption of contaminated shellfish (Iwamoto et al., 2010).

Enumeration of E. coli, a fecal bacterial indicator, is the standard way to assess the level of fecal microorganisms in water and shellfish and indirectly, to estimate the associated potential risk to human health from all waterborne enteric pathogens (e.g., through classification of bathing areas and shellfish-harvesting areas; Anonymous, 2004). However, in addition to being a fecal indicator and a commensal bacterium, E. coli includes strains that can be pathogenic to humans. These can cause diarrhea and extra-intestinal diseases after acquiring virulence genes by genetic mobile elements such as bacteriophages, pathogenicity islands, and plasmids (Touchon et al., 2009). Pathogenic E. coli are distributed into diarrheagenic $E$. coli pathotypes including enterotoxigenic E. coli (ETEC), Shigella/enteroinvasive E. coli (EIEC), enteroaggregative E. coli (EAEC), diffusely adherent E. coli (DAEC), enteropathogenic E. coli (EPEC), Shiga toxinproducing E. coli (STEC; for review, Croxen et al., 2013) and into extra-intestinal E. coli pathotypes (Russo and Johnson, 2000).

Escherichia coli occurrence in seafood is considered a sanitary case and may represent a risk to the consumers if related to diarrheagenic E. coli (for review, Costa, 2013).

The study presented here focuses on EPEC (one of the main causes of diarrhea in infants) and STEC (an emerging zoonotic pathogen).

Enteropathogenic E. coli is an important cause of infantile watery diarrhea, which is more frequently encountered in lowincome countries than in the industrialized world (Nataro and Kaper, 1998). They are known to create distinctive lesions on the surface of intestinal epithelial cells, called attaching and effacing (A/E) lesions. This property is encoded by genes, including eae, grouped together in a pathogenicity island referred to the locus of enterocyte effacement' (LEE; Paton and Paton, 1998). EPEC is transmitted from host to host via the fecal-oral route through contaminated surfaces, waters and food and human carriers. Humans, including symptomatic and asymptomatic children and asymptomatic adults, are the most likely source (Levine and Edelman, 1984). Animals, such as cattle and wildlife species, have been found to be additional sources (Singh et al., 2015). Twelve O serogroups have been recognized as EPEC by the World Health
Organization: O26, O55, O86, O111, O114, O119, O125, O126, O127, O128, O142, and O158 (WHO, 1987).

Shiga-toxin producing Escherichia coli are responsible for the mucoid-bloody diarrhea that can progress to hemolytic uremic-syndrome (HUS), especially in children. One of the most important pathogenicity factors produced by STEC strains is the Shiga toxin (Stx), encoded by a lambdoid bacteriophage (O'Brien et al., 1984). Shiga toxins can be divided into two types, Stx1 (almost identical to Shiga toxin produced by Shigella dysenteriae type 1) and Stx2, encoded by stx 1 and stx 2 genes, respectively (Scheutz et al., 2012). In addition, the STEC strains are often able to produce the $\mathrm{A} / \mathrm{E}$ lesions as a result of the presence of the LEE pathogenicity island, as in EPEC. This subset of STEC strains is also known as enterohemorrhagic E. coli (EHEC; McDaniel et al., 1995). Instead of this LEE pathogenicity island, they can also possess the auto-agglutinating adhesin factor designated Saa (STEC autoagglutinating adhesin; Paton et al., 2001). Adhesion to the intestinal mucosa is an essential step in the infection cycle of E. coli, which contributes to pathogenesis in humans. Other factors are involved in the virulence of STEC but also of EPEC, such as enterohemolysin A, encoded by the ehxA gene and associated with cytotoxic effects on endothelial cells that may contribute to the development of HUS (Jiang et al., 2015). STEC infections have been reported following the ingestion of contaminated food or water, after bathing in contaminated waters or contact with animals (for review, Croxen et al., 2013). The principal reservoir of STEC is the digestive tract of animals, particularly of cattle that are healthy carriers (Bibbal et al., 2015). Other animals, such as sheep, goats, swine, birds, and other wild animals, as well as humans, can also harbor STEC (Mora et al., 2012; Chandran and Mazumder, 2013).

Most human illness is caused by the serotype STEC O157:H7 (Paton and Paton, 1998). However, it is becoming evident that non-O157 isolates belonging to the serogroups O26, O45, O91, O103, O111, O113, O121, O145 also cause significant human illness (Mellmann et al., 2009; USDA, 2011). In Europe, O157:H7 and the four serotypes: O26:H11, O103:H2, O111:H8, and $\mathrm{O} 145: \mathrm{H} 28$ are the most widely implicated in human STEC infections, constituting the five highly pathogenic serotypes (EFSA, 2013).

Shiga-toxin producing Escherichia coli and EPEC contamination of the environment may occur through the spreading of livestock manure, animal waste on pastures, via wastewaters from slaughterhouses or from treatment plant effluents and by wildlife (Muniesa et al., 2006; Singh et al., 2015).

In such environments, STEC and EPEC strains are exposed to various stresses, such as low temperature or nutrient depletion and the ability to form biofilm could be an advantage to increase persistence (Vogeleer et al., 2014). 
To date, very few studies have focused on the detection and isolation of pathogenic E. coli belonging to the STEC and EPEC pathovars in coastal environments (Gourmelon et al., 2006; Bennani et al., 2011). The aim of the study presented here was to detect and characterize STEC and EPEC strains from French shellfish-harvesting areas and their upstream watershed in order to assess the diversity of these pathogenic E. coli potentially present in this type of hostile environment. For this purpose, during a 2-years study, shellfish batches, freshwater, seawater, and surface sediment samples from three selected shellfish-harvesting areas and their upstream watersheds, the location of intensive livestock activities (cattle, swine, poultry, and/or sheep), were analyzed monthly to evaluate the presence of STEC and EPEC strains.

\section{MATERIALS AND METHODS}

\section{Sampling Locations and Sample Description}

Shellfish, water, and surface sediment samples were collected from three shellfish-harvesting sites on the French coast of within the Eastern English Channel and their watersheds. One of these sites, located in Brittany (site 1), corresponded to a $121 \mathrm{~km}^{2}$ watershed, characterized by intensive livestock farming (cattle, swine, and poultry), with a human population of about 9,000 inhabitants. The two others were situated in Normandy; site 2 was characterized by a $1,000 \mathrm{~km}^{2}$ catchment, with large livestock farming (cattle, sheep, swine, and poultry) and about 40,000 inhabitants, while the second site (site 3) corresponded to a $50 \mathrm{~km}^{2}$ watersheds with large livestock farming (cattle, sheep, and swine) and about 7,000 inhabitants. These two latter watersheds are geographically closer together than the Brittany site (location of the sites Supplementary Figure S1). The three shellfish-harvesting areas are classified as category B for oysters (Crassostrea gigas) and mussels (Mytilus edulis) and as category C for common cockles (Cerastoderma edule) according to European regulation (European Directive 91/492/EEC; Anonymous, 2004). Shellfish from category B shellfish-harvesting areas must be depurated before being sold and shellfish from category $\mathrm{C}$ areas must be relayed at least 2 months prior to sale for consumption. Shellfish [oyster, mussel, and common cockle batches (site 1, $n=120$; site 2, $n=72$; and site 3, $n=46$ )] and freshwater samples from nine sampling sites upstream of shellfish-harvesting areas (site $1, n=96$; site $2, n=72$; site $3, n=48$ ) were collected monthly from February 2013 to January 2015, whereas surface sediment samples ( site $1, n=13$; site $2, n=13$; site 3 , $n=13$ ) were collected from February 2013 to January 2014 and seawater samples ( site $1, n=12$ ) from February 2014 to January 2015.

\section{Isolation of STEC and EPEC Strains}

Samples were transported in insulated cooler boxes to the laboratory and analyzed within $24 \mathrm{~h}$. After opening, total shellfish flesh, including shellfish flesh and intravalvular liquid, were homogenized in a commercial blender (Waring Products Division, Torrington, CT, USA) for $60 \mathrm{~s}$ at high speed.
Twenty-five grams of homogenized total shellfish flesh were inoculated into $225 \mathrm{ml}$ of buffered peptone water (BPW). For surface sediments, $10 \mathrm{~g}$ were introduced into the same volume of BPW. For water samples, $1 \mathrm{~L}$ was filtered using $0.45 \mu \mathrm{m}$ cellulose membranes (Pall Gelman GN-6 Metricel; Pall Corporation, St Germain-en-Laye, France) and the filter was placed in $225 \mathrm{ml}$ of BPW. Incubation was performed at $37^{\circ} \mathrm{C}$ for $24 \mathrm{~h}$.

Shiga-toxin producing Escherichia coli and EPEC strains were isolated from the environmental samples using three additional protocols. The first one, described by Balière et al. (2015), involves application of the ISO/TS-13136 method, which focuses on isolation of strains belonging to the five highly pathogenic serotypes and was applied to samples collected from February 2013 to February 2014. The two other protocols involve the isolation of STEC and EPEC with or without an enrichment step and independently from the serotype. These were applied to samples collected from February 2013 to January 2015.

For the protocol with an enrichment step (described in Balière et al., 2015), DNA was extracted from $500 \mu \mathrm{L}$ of each BPW enrichment broth using NucliSENS Nucleic Acid Extraction Reagents for miniMAG (BioMérieux, Marcy l'Etoile, France), according to the manufacturer's instructions. The stx and eae genes were detected by real-time PCR (Agilent MX3000P, Waldbronn, Germany), using primers and probes published previously (Nielsen and Andersen, 2003; Perelle et al., 2007), according to the ISO/TS-13136: 2012 technical specification, with slight modifications concerning the PCR cycles [denaturation for $10 \mathrm{~s}$ at $95^{\circ} \mathrm{C}$, primer annealing for $5 \mathrm{~s}$ at $55^{\circ} \mathrm{C}$, and extension for $25 \mathrm{~s}$ at $60^{\circ} \mathrm{C}(45$ cycles $\left.)\right]$. BPW broths identified positive for stx and eae were screened for STEC and EPEC isolates by streaking $1 \mu \mathrm{L}$ of these broths onto Tryptone-Bile-Xglucuronide agar (TBX; AES chemunex, Bruz, France) and onto chromID ${ }^{\mathrm{TM}}$ agar (BioMérieux), followed by incubation at $44^{\circ} \mathrm{C}$ for $24 \mathrm{~h}$.

The final protocol to be used involves the screening of $E$. coli isolated directly from the water and shellfish samples without an enrichment step. For this protocol, 1, 10, and $100 \mathrm{ml}$ of water were filtered through $0.45 \mu \mathrm{m}$ cellulose membranes and the filters were placed onto TBX agar. For shellfish, $10 \mathrm{~g}$ of blended total shellfish flesh were distributed onto five empty and sterile plates with overlay super-cooled TBX agar. All TBX plates were incubated at $44^{\circ} \mathrm{C}$ for $24 \mathrm{~h}$. Presumptive STEC and EPEC isolates were confirmed by real-time PCRs targeting stx 1 , st $x 2$, and eae genes, as described above after a DNA extraction of each isolate by boiling at $100^{\circ} \mathrm{C}$, for $15 \mathrm{~min}$.

The STEC and EPEC isolates were characterized using several protocols as described below.

\section{Serotyping}

The serotypes of the STEC and EPEC strains were characterized using the serotyping method by agglutination, as described by Blanco et al. (2003).

More precisely, determination of $\mathrm{O}$ and $\mathrm{H}$ antigens was carried out by agglutination as previously described (Guinée et al., 1981), employing all available $\mathrm{O}$ (O1-O185) and 
$\mathrm{H}$ (H1-H56) antisera. All antisera were absorbed with the corresponding cross-reacting antigens to remove the nonspecific agglutinins. The $\mathrm{O}$ and $\mathrm{H}$ antisera were produced in the Laboratorio de Referencia de E. coli (USC, Lugo, Spain). Isolates that did not react with $\mathrm{O}$ antisera were considered as non-typeable (ONT) and those non-motile were HNM.

\section{Detection of Enterohemolysin and Adhesin}

The presence of ehxA (encoding enterohemolysin A) and saa (encoding STEC autoagglutining adhesin) genes in these isolates was investigated by conventional PCR using primers previously described by Paton and Paton (2002).

\section{Phylogenetic Group}

Isolates were classified into the four main E. coli phylogenetic groups (A, B1, B2, or D) using a conventional triplex PCR method based on the detection of two genes, $\operatorname{chuA}$, required for heme transport in enterohemorrhagic O157:H7 E. coli, yjaA, initially identified in the recent complete genome sequence of $E$. coli $\mathrm{K}$ 12 , for which the function is unknown, and of an anonymous DNA fragment designated TSPE4.C2 using primers described previously by Clermont et al. (2000).

\section{Pulsed-field Gel Electrophoresis}

The genetic relatedness of the isolates was studied by the pulsed-field gel electrophoresis method (PFGE) according to Bidet et al. (2005). Isolated strains were inoculated in nutrient broth containing $1.3 \% \mathrm{NaCl}$ (Bio-Rad, Marnes-la-coquette, France) and incubated at $37^{\circ} \mathrm{C}$ for $24 \mathrm{~h}$. Bacterial DNA was extracted from $400 \mu \mathrm{l}$ of the enrichment broth using the $\mathrm{CHEF}$ Bacterial Genomic DNA Plug Kit (Bio-Rad) according to the manufacturer's recommendations. Bacterial DNA was digested for between 16 and $20 \mathrm{~h}$ at $37^{\circ} \mathrm{C}$ with the restriction endonuclease XbaI (Roche Diagnostic, Meylan, France) according to the manufacturer's recommendations. Each electrophoresis was performed using a lambda ladder molecular mass marker (Bio$\mathrm{Rad}$ ) for the normalization of gel images. The migration was performed on a $1 \%$ agarose gel using the CHEF-DRIII apparatus (Bio-Rad) at $6 \mathrm{~V} \mathrm{~cm}^{-1}$ for $27 \mathrm{~h}$, with pulse times varying linearly between two and 49 s. The bacterial DNA restriction patterns were analyzed using the Bionumerics software 7.5 (Applied Maths, Kortrijk, Belgium). The similarity of PFGE profiles was compared and a dendrogram was created using the band-based Dice unweighted-pair group method, using average linkages (UPGMA), based on $1 \%$ position tolerance and $0 \%$ position optimization. Branch quality was evaluated using Cophenetic correlation. PFGE patterns were considered clonally related when they had a similarity coefficient higher than $80 \%$.

\section{Multilocus Sequencing Typing}

The genetic relatedness of the isolates was also studied using the multilocus sequencing typing method (MLST). Fragments of seven housekeeping genes, i.e., adk (adenylate kinase), fumC (fumarate hydratase), gyrB (DNA gyrase), icd (isocitrate/isopropylmalate dehydrogenase), $m d h$ (malate dehydrogenase), purA (adenylosuccinate dehydrogenase), and recA (ATP/GTP binding motif) were amplified and sequenced using suitable primers (Wirth et al., 2006) with minor modifications for the $\operatorname{rec} A$ primers (recAR $5^{\prime}$-TCG-TCGAAA-TCT-ACG-GAC-CGG-A-3'; recAF1 5'-ACC-TTT-GTAGCT-GTA-CCA-CG-3'). The PCR cycle included denaturation for $60 \mathrm{~s}$ at $95^{\circ} \mathrm{C}$, primer annealing for $60 \mathrm{~s}$ at $56^{\circ} \mathrm{C}$ (for $a d k, \operatorname{pur} A, \operatorname{rec} A$, and $i c d$ ), at $65^{\circ} \mathrm{C}$ (for $m d h$ and $g y r B$ ), or at $68^{\circ} \mathrm{C}$ (for fumC), and extension for $60 \mathrm{~s}$ at $72^{\circ} \mathrm{C}(35$ cycles) in MJ Research PTC-200 (DNA Engine, Waltham, MA, USA). Sequencing was performed in both directions with the fluorescent dye terminator Sanger method on ABI3730 (Applied Biosystem) by Eurofins Genomics (Ebersberg, Germany). The alleles and sequence types (ST) were assigned in accordance with the E. coli MLST database (http://mlst.warwick.ac.uk/mlst/ $\mathrm{dbs} /$ Ecoli).

\section{Static Biofilm Formation Assay}

A biofilm formation assay was performed as previously described by Tremblay et al. (2015). In addition to the incubation temperature of $30^{\circ} \mathrm{C}$, the ability to form biofilms was also tested at $18^{\circ} \mathrm{C}$, in order to reproduce marine temperate environmental conditions (Moldoveanu, 2012). Briefly, overnight cultures at $37^{\circ} \mathrm{C}$ in $\mathrm{LB}$ media were diluted $(1: 100)$ in $5 \mathrm{ml}$ of $\mathrm{M} 9$ medium with glucose $(0.4 \% \mathrm{wt} / \mathrm{vol})$ and minerals (1.16 $\mathrm{mM} \mathrm{MgSO}_{4}$, $2 \mu \mathrm{M} \mathrm{FeCl}_{3}, 8 \mu \mathrm{M} \mathrm{CaCl}$, and $16 \mu \mathrm{M} \mathrm{MnCl}_{2}$ ) and incubated for $24 \mathrm{~h}$ at $37^{\circ} \mathrm{C}$. These cultures were diluted (1:100) in M9 medium supplemented with glucose and minerals and were inoculated in triplicate into microtitre plates (Costar 3370; Corning, NY, USA). After $24 \mathrm{~h}$ of incubation at 18 or $30^{\circ} \mathrm{C}$, unattached cells were removed by washing three times with phosphate-buffered saline (PBS). Plates were dried at $37^{\circ} \mathrm{C}$ for $15 \mathrm{~min}$ and biofilms were stained with crystal violet $(0.1 \%$ wt/vol) for $2 \mathrm{~min}$. After removal of crystal violet solution, the biofilms were washed three times with PBS and dried at $37^{\circ} \mathrm{C}$ for $15 \mathrm{~min}$. The biofilm stain was dissolved with $150 \mu \mathrm{l}$ of $80 \%$ ( $\mathrm{vol} / \mathrm{vol})$ ethanol and $20 \%$ ( $\mathrm{vol} / \mathrm{vol}$ ) acetone and biofilms were quantified by measuring the absorbance at $590 \mathrm{~nm}\left(\mathrm{OD}_{590}\right)$ with a microplate reader (Powerwave; BioTek Instruments, Winooski, VT, USA). The results for the static biofilms formed at 18 and $30^{\circ} \mathrm{C}$ were compared using two-way analysis of variance (ANOVA) followed by a Bonferroni post hoc comparison using GraphPad Prism, version 4.02 (GraphPad Software, San Diego, CA, USA). Strains were divided into three groups based on the $\mathrm{OD}_{590}$ of bacterial biofilm: strong $\left(A_{590}>0.6\right)$, medium $\left(0.6 \geq A_{590} \geq 0.3\right)$ and weak or none $\left(\mathrm{A}_{590}<0.3\right)$.

\section{Antibiotic Resistance}

Antimicrobial susceptibility testing based on the disk diffusion method was performed on a selection of STEC and EPEC isolates. Sixteen antibiotics were tested: Tobramycin $(10 \mu \mathrm{g})$, Fosfomycin $(50 \mu \mathrm{g})$, Cefalotin $(30 \mu \mathrm{g})$, Imipenem $(10 \mu \mathrm{g})$, Tigecyclin $(15 \mu \mathrm{g})$, Gentamycin $(15 \mu \mathrm{g})$, Cefotaxim $(30 \mu \mathrm{g})$, Cefoxitin $(30 \mu \mathrm{g})$, Doxycyclin $(30 \mu \mathrm{g})$, Ciprofloxacin $(5 \mu \mathrm{g})$, Augmentin $(20 \mu \mathrm{g}$ 
amoxicilin; $10 \mu \mathrm{g}$ clavulanic acid), Ticarcillin (75 $\mu \mathrm{g})$, Bactrim (1.25 $\mu \mathrm{g}$ trimethoprim; $23.75 \mu \mathrm{g}$ sulfamethoxazol), Nalidixic acid (30 $\mu \mathrm{g})$, Amikacin $(30 \mu \mathrm{g})$, Amoxicillin (25 $\mu \mathrm{g})$ on MuellerHinton medium (AES chemunex, Bruz, France). Plates were incubated at $37^{\circ} \mathrm{C}$ for $24 \mathrm{~h}$.

\section{Environmental Data and Statistical Analysis}

Rainfall data (2-days cumulative rainfall before sampling date) were provided by the meteorological stations from Meteo France at Pleurtuit (site 1) and at Coutances (sites 2 and 3). The water temperature was measured manually at each sampling. The data on temperature and precipitation were categorized into three groups whose boundaries were defined so that they are likely to categorize the data significantly for the studied sites and they allow to have in each category a number of sample consistent with a reliable statistical analysis. Comparisons of STEC and EPEC prevalence between the type of samples, the site, the season, the temperature and the precipitation were analyzed by the chi-square test. A $p$-value of $<0.05$ was considered statistically significant.

\section{RESULTS}

\section{Detection and Isolation of STEC and EPEC Strains}

The stx gene was detected in $30.3,85.9,41.7$, and $28.2 \%$ of shellfish, freshwater, seawater and surface sediment enrichment broths, respectively (Table 1). The eae gene was detected in 74.8, 100,100 , and $43.6 \%$ of shellfish, freshwater, seawater, and surface sediment enrichment broths, respectively (Table 1). STEC were isolated from $5.0 \%$ of the 238 shellfish, $5.6 \%$ of the 216 freshwater, $8.3 \%$ of the 12 seawater, and $2.6 \%$ of the 39 surface sediment samples analyzed, whereas EPEC were isolated from 8.0, 21.3, and $33.3 \%$ of the shellfish, freshwater, and seawater samples, respectively. No EPEC were isolated from surface sediments (Table 2). A total of 57 STEC and 117 EPEC isolates were obtained from these samples. However, as 29 STEC and 28 EPEC had identical serotypes, PFGE and MLST patterns, virulence gene profiles, and phylogroups to other isolates cultivated from the same samples, they were considered to be replicates and not retained. The remaining 28 STEC and 89 EPEC isolates represented 0.2 and $0.7 \%$ of the total E. coli $(n=12,016)$, respectively (Table 3 ).
TABLE 2 | Isolation of STEC and EPEC as regard to sample parameters.

\begin{tabular}{|c|c|c|c|}
\hline $\begin{array}{l}\text { Sample } \\
\text { parameter }\end{array}$ & $\begin{array}{c}\text { No. of } \\
\text { samples }\end{array}$ & $\begin{array}{c}\text { No. of samples } \\
\text { with at least one } \\
\text { STEC isolate }(\%)^{a}\end{array}$ & $\begin{array}{c}\text { No. of samples } \\
\text { with at least one } \\
\text { EPEC isolate }(\%)^{a}\end{array}$ \\
\hline \multicolumn{4}{|l|}{ Type } \\
\hline Shellfish & 238 & $12(5.0)$ & $19(8.0)$ \\
\hline Freshwater & 216 & $12(5.6)$ & 46 (21.3) \\
\hline Seawater & 12 & 1 (8.3) & 4 (33.3) \\
\hline $\begin{array}{l}\text { Superficial } \\
\text { sediment }\end{array}$ & 39 & $1(2.6)$ & 0 \\
\hline$x^{2}$ test & & $p=0.845$ & $p=3.0910^{-5}$ \\
\hline \multicolumn{4}{|l|}{ Site } \\
\hline Site 1 & 241 & $10(4.1)$ & $34(14.1)$ \\
\hline Site 2 & 157 & $7(4.5)$ & $20(12.7)$ \\
\hline Site 3 & 107 & $9(8.4)$ & $15(14.0)$ \\
\hline$x^{2}$ test & & $p=0.244$ & $p=0.931$ \\
\hline \multicolumn{4}{|l|}{ Season } \\
\hline Fall & 146 & $4(2.7)$ & $11(7.5)$ \\
\hline Summer & 126 & 17 (13.5) & $22(17.5)$ \\
\hline Autumn & 124 & $3(2.4)$ & $24(19.4)$ \\
\hline Winter & 109 & $2(1.8)$ & $12(11.0)$ \\
\hline$x^{2}$ test & & $p=4.4410^{-5}$ & $p=0.0314$ \\
\hline \multicolumn{4}{|c|}{ Temperature $\left({ }^{\circ} \mathrm{C}\right)$} \\
\hline $0-<10$ & 172 & 5 (2.9) & $15(8.7)$ \\
\hline $10-<15$ & 189 & $14(7.4)$ & $29(15.3)$ \\
\hline $15->15$ & 144 & $7(4.9)$ & $25(17.4)$ \\
\hline$x^{2}$ test & & $p=0.167$ & $p=0.086$ \\
\hline \multicolumn{4}{|c|}{ Precipitation $(\mathrm{mm})^{\mathrm{b}}$} \\
\hline $0-<1$ & 253 & $17(6.7)$ & $30(11.9)$ \\
\hline $1-<10$ & 144 & $5(3.5)$ & $21(14.6)$ \\
\hline $10->10$ & 108 & $4(3.7)$ & 18 (16.7) \\
\hline$x^{2}$ test & & $p=0.296$ & $p=0.495$ \\
\hline Total & 505 & $26(5.1)$ & 69 (13.7) \\
\hline
\end{tabular}

a Percentage calculated based on the total of no. samples for each type of sample. brecipitation: 2-days cumulative rainfall before sampling date.

Shiga-toxin producing Escherichia coli strains represented 0.2, 0.2 , and $0.3 \%$, of the isolated $E$. coli from sites $1-3$, respectively. EPEC strains represented $0.8,0.6$, and $0.7 \%$ of the isolated E. coli from sites $1-3$, respectively (Table 3 ).

For the three sites, the majority of STEC strains derived from freshwater samples $(50,57.1$, and $44.4 \%$ of samples from sites $1-3$, respectively) and from shellfish batches $(41.7,42.9$, and $44.4 \%$ in the sites 1-3, respectively; Table 3). Only two STEC strains were isolated from seawater and surface sediment samples from sites

TABLE 1 | Prevalence of stx and eae genes in shellfish, freshwater, seawater, and superficial sediment enrichment broths.

\begin{tabular}{|c|c|c|c|c|}
\hline Type of sample & No. of samples & No. of stx-positive broth (\%) & No. of eae-positive broth (\%) & No. of stx- and eae-positive broth (\%) ${ }^{a}$ \\
\hline Shellfish & 238 & 72 (30.3) & $178(74.8)$ & 64 (26.9) \\
\hline Freshwater & 216 & $196(85.9)$ & $216(100)$ & 196 (85.9) \\
\hline Seawater & 12 & $5(41.7)$ & $12(100)$ & $5(41.7)$ \\
\hline Superficial sediment & 39 & $11(28.2)$ & $17(43.6)$ & $8(20.5)$ \\
\hline Total & 505 & $284(56.2)$ & 423 (83.7) & $273(54.1)$ \\
\hline
\end{tabular}

apercentage calculated based on the total of no. samples for each type of sample. 
TABLE 3 | Number of STEC and EPEC strains isolated from shellfish, freshwater, seawater, and superficial sediment samples collected in the three shellfish-harvesting areas and their watersheds, as regard to the total number of $E$. coli isolates.

\begin{tabular}{|c|c|c|c|c|c|}
\hline Type of sample & Total $(\%)^{a}$ & Shellfish (\%) & Freshwater (\%) & Seawater (\%) & Superficial sediment (\%) \\
\hline \multicolumn{6}{|l|}{ Site 1} \\
\hline No. E. coli isolates & 5,676 & 1,343 & 3,410 & 225 & 30 \\
\hline No. STEC strains & $12(0.2)$ & $5(41.7)^{b}$ & $6(50.0)^{b}$ & $1(8.3)^{b}$ & 0 \\
\hline No. EPEC strains & $47(0.8)$ & $8(17.4)^{b}$ & $35(76.1)^{b}$ & $4(8.5)^{b}$ & 0 \\
\hline \multicolumn{6}{|l|}{ Site 2} \\
\hline No. E. coli isolates & 3,682 & 757 & 2,925 & $n d^{c}$ & 4 \\
\hline No. STEC strains & $7(0.2)$ & $3(42.9)^{b}$ & $4(57.1)^{b}$ & nd & 0 \\
\hline No. EPEC strains & $23(0.6)$ & $10(43.5)^{b}$ & $13(56.5)^{b}$ & nd & 0 \\
\hline \multicolumn{6}{|l|}{ Site 3} \\
\hline No. E. coli isolates & 2,658 & 678 & 2,036 & nd & 83 \\
\hline No. STEC strains & $9(0.3)$ & $4(44.4)^{b}$ & $4(44.4)^{b}$ & nd & $1(11.1)^{b}$ \\
\hline No. EPEC strains & $19(0.7)$ & $5(26.3)^{b}$ & $14(73.7)^{b}$ & nd & 0 \\
\hline \multicolumn{6}{|c|}{ Total of the three sites } \\
\hline No. E. coli isolates & 12,016 & 2,778 & 8,371 & 225 & 117 \\
\hline No. STEC strains & $28(0.2)$ & $12(42.9)^{b}$ & $14(50.0)^{b}$ & $1(3.6)^{b}$ & $1(3.6)^{b}$ \\
\hline No. EPEC strains & $89(0.7)$ & $23(25.8)^{b}$ & $62(69.7)^{b}$ & $4(4.5)^{b}$ & 0 \\
\hline
\end{tabular}

a Percentage calculated based on the total of no. E. coli isolates from each sites. ${ }^{b}$ Percentage calculated based on the total of no. STEC or EPEC strains isolated from the three sites. ${ }^{c}$ nd: non-determined.

1 and 3, respectively. The majority of EPEC strains derived from the freshwater samples $(76.1,56.5$, and $73.7 \%$ of samples from sites $1-3$, respectively) and the remaining EPEC derived from shellfish batches $(17.4,43.5$, and $26.3 \%$, respectively) and seawater samples ( $8.5 \%$ only in the site 1 ; Table 3 ).

Nearly one third of the STEC strains were obtained from samples collected in May 2013 (32.1\%, 9/28), whereas the EPEC strains were mostly obtained from samples collected in November $2013(21.3 \%, 19 / 89)$ and August 2014 (12.4\%, 11/89; Table 4). The entire sample set demonstrated a seasonal effect with potential pathogenic $E$. coli as STEC strains were significantly more frequently isolated in Summer and EPEC strains in Summer and Autumn $(p<0.05$; Table 2). However, no correlation between the prevalence of both STEC and EPEC and pluviometry nor temperature was observed (Table 2).

\section{Virulence Gene Profiles}

By considering the presence of a single virulence gene or a combination of the four virulence genes investigated (i.e., stx, eae, $e h x A$, and saa) in the 117 STEC or EPEC strains, eight virulence gene profiles were found. The most frequent profile presented the eae gene only ( $70.1 \%$ of the strains) followed by the profile presenting the stx 2 gene only $(11.1 \%)$ and the profile presenting the $s t x 1$ gene only $(7.7 \%)$. Seven strains $(6.0 \%)$ were shown to possess the eae and ehxA genes. The stx1-stx2-ehxA-saa profile was found in three strains and three other virulence gene profiles were observed only once, i.e., the stx1-eae-ehxA, the stx1-stx2-saa, and the stx2-ehxA-saa profiles (Table 4).

Seven STEC strains carrying stx 1 , three carrying stx2, and two carrying both stx 1 and stx 2 genes were isolated from the site 1 whereas three STEC strains harboring the stx 1 gene, 11 the stx2 gene, and two presenting both stx 1 and st $x 2$ genes were recovered from sites 2 and 3.

\section{Phylogroups}

The STEC strains $(n=28)$ were mainly distributed among the phylogroups A, B1, and D (39.3, 35.7, 21.4\%, respectively). Only one strain belonged to phylogroup B2. The EPEC strains ( $n=89$ ) belonged to all the phylogroups; the strains from phylogroup B1 and B2 (38.2 and 38.2\%, respectively) being more prevalent than those from phylogroups A and D (18.0 and $5.7 \%$, respectively; Table 5). More precisely, at site 1 , the STEC strains were mainly divided between phylogroups B1 and D. At sites 2 and 3, the STEC strains were divided between phylogroups A and B1. At sites 1-3, the EPEC strains belonged to all the investigated phylogroups, with a majority belonging to phylogroups B1 and B2.

\section{Serotyping}

The 117 (STEC or EPEC) strains selected in this study belonged to $44 \mathrm{O}$ antigens and $24 \mathrm{H}$ antigens and presented 75 distinguishable serotypes (Table 4). Among all strains, 13 strains were nontypable (NT) for the O antigen [ONT:H2 $(n=1)$, ONT:H31 $(n=1)$, ONT:H34 $(n=1)$, ONT:H6 $(n=6)$, ONT:H8 $(n=2)$, ONT:H10 $(n=1)$, ONT:H11 $(n=1)]$ and 24 strains were uncharacterized for the $\mathrm{H}$ antigen (HNM: non-motile or HNT: non-typable).Two strains were non-typable for either antigens (ONT:HNT).

Eighteen different serotypes (O:H) were identified among the STEC strains. Only one STEC belonging to one of the five highly pathogenic serotypes was isolated: an $\mathrm{O} 26: \mathrm{H} 11$ st $x 1^{+}$, $e a e^{+}$, and $e h x A^{+}$strain, from a mussel batch. One strain from serotype O91:H21 and carrying stx1, stx2, ehxA, and saa genes was also identified among the STEC strains. The most detected serotype among the STEC strains was the O100:HNM $(n=9)$. Fifteen additional serotypes (O149:H31/HNM, O154:H31/HNM, O130:H11, O15:H16, O185:H28, O2:H32, O28:H1, O63:H11, O76:H19, O8:H12, O88:H25, ONT:H10, and ONT:H11) were 
TABLE 4 | Characteristics of STEC and EPEC strains isolated from the three French shellfish-harvesting sites from the Eastern English Channel coastal area and their watersheds.

\begin{tabular}{|c|c|c|c|c|c|}
\hline $\begin{array}{l}\text { Serotype (no. } \\
\text { of isolate) }\end{array}$ & $\begin{array}{l}\text { Virulence gene (no. } \\
\text { of isolate) }\end{array}$ & $\begin{array}{l}\text { Sample origin (no. } \\
\text { of isolate) }\end{array}$ & $\begin{array}{l}\text { Sampling site } \\
\text { (no. of isolate) }\end{array}$ & Sampling month-year & $\begin{array}{l}\text { Precipitation } \\
\quad(\mathrm{mm})\end{array}$ \\
\hline \multicolumn{6}{|l|}{ STEC } \\
\hline \multirow{3}{*}{ O100:HNM (9) } & & $\mathrm{FW}(1), \mathrm{SFo}(1), \mathrm{SFm}(1)$ & 3 & May-13 & 0.1 \\
\hline & & $\mathrm{SFm}(1), \mathrm{S}(1)$ & 3 & June-13 & 6.1 \\
\hline & & SFm & 2 & March-14 & 0.1 \\
\hline $\mathrm{O} 2: \mathrm{H} 32(1)$ & $s t \times 2$ & SW & 1 & February-14 & 0 \\
\hline \multirow[t]{2}{*}{ O8:H19(2) } & $s t \times 2$ & FW & 3 & June-14 & 0 \\
\hline & & FW & 3 & July-14 & 1.4 \\
\hline O149:H1(1) & $s t \times 1$ & $\mathrm{FW}$ & 1 & April-13 & 1.6 \\
\hline O149:HNM(1) & $s t \times 1$ & FW & 1 & April-13 & 1.6 \\
\hline O88:H25(1) & $s t \times 1$ & $\mathrm{FW}$ & 2 & September-14 & 0.4 \\
\hline ONT:H10(1) & $s t \times 1$ & FW & 2 & April-14 & 0.3 \\
\hline O26:H11(1) & stx1+eae+ehxA & SFm & 1 & November-13 & 15.4 \\
\hline O63:H6(1) & stx2+ehxA+saa & $\mathrm{FW}$ & 1 & November-14 & 24.0 \\
\hline ONT:H11(1) & $s t \times 1+s t \times 2+s a a$ & FW & 1 & May-13 & 1.8 \\
\hline O185:H28(1) & stx $1+s t \times 2+e h \times A+s a a$ & FW & 2 & Apr-13 & 1.6 \\
\hline O130:H11(1) & stx $1+s t \times 2+e h \times A+s a a$ & FW & 1 & December-13 & 0 \\
\hline O91:H21(1) & stx $1+s t \times 2+e h \times A+s a a$ & FW & 3 & May-13 & 1.8 \\
\hline \multicolumn{6}{|l|}{ EPEC } \\
\hline O103:H25(1) & eae & $\mathrm{FW}$ & 3 & March-14 & 0.1 \\
\hline O116:H2O(1) & eae & $\mathrm{FW}$ & 1 & November-13 & 15.4 \\
\hline \multirow[t]{2}{*}{ O125:H6(2) } & eae & $\mathrm{FW}$ & 1 & November-13 & 15.4 \\
\hline & & FW & 2 & September-14 & 0.4 \\
\hline O128:H2(1) & eae & FW & 2 & November-13 & 0 \\
\hline \multirow[t]{2}{*}{ O137:H6(2) } & eae & FW & 1 & August-13 & 1.0 \\
\hline & & FW & 3 & January-15 & 2.3 \\
\hline O145:H34(1) & eae & FW & 1 & July-14 & 6.5 \\
\hline O146:H21(1) & eae & SFm & 3 & August-14 & 26.0 \\
\hline O146:H6(1) & eae & SFc & 2 & September-14 & 0.4 \\
\hline \multirow[t]{2}{*}{ O15:H2(2) } & eae & $\mathrm{FW}$ & 3 & August-14 & 26.0 \\
\hline & & SFm & 2 & January-15 & 2.3 \\
\hline O153:H21(1) & eae & $\mathrm{FW}$ & 1 & January-14 & 7.2 \\
\hline O157:H16(1) & eae & FW & 1 & July-14 & 6.5 \\
\hline O159:H7(1) & eae & $\mathrm{FW}$ & 1 & November-14 & 24.0 \\
\hline O167:H3(1) & eae & $\mathrm{FW}$ & 1 & August-13 & 2.8 \\
\hline \multirow[t]{2}{*}{ O179:H31(2) } & eae & $\mathrm{FW}$ & 1 & January-14 & 7.2 \\
\hline & & FW & 3 & June-14 & 0 \\
\hline $\mathrm{O} 2: \mathrm{H} 45(1)$ & eae & $\mathrm{FW}$ & 2 & December-13 & 0 \\
\hline O2O:HNT(1) & eae & SW & 1 & April-14 & 0 \\
\hline
\end{tabular}


TABLE 4 | Continued

\begin{tabular}{|c|c|c|c|c|c|}
\hline $\begin{array}{l}\text { Serotype (no. } \\
\text { of isolate) }\end{array}$ & $\begin{array}{c}\text { Virulence gene (no. } \\
\text { of isolate) }\end{array}$ & $\begin{array}{c}\text { Sample origin (no. } \\
\text { of isolate) }\end{array}$ & $\begin{array}{l}\text { Sampling site } \\
\text { (no. of isolate) }\end{array}$ & Sampling month-year & $\begin{array}{l}\text { Precipitation } \\
\text { (mm) }\end{array}$ \\
\hline \multirow[t]{2}{*}{ O23:H8(2) } & eae & FW & 2 & August-13 & 0.7 \\
\hline & & SFC & 2 & August-14 & 26.0 \\
\hline $\mathrm{O} 25: \mathrm{H} 2(1)$ & eae & FW & 1 & September-14 & 0 \\
\hline O28:H16(1) & eae & SFm & 1 & November-13 & 15.4 \\
\hline O29:H19(1) & eae & FW & 2 & October-13 & 22.8 \\
\hline O33:H6(1) & eae & FW & 1 & February-14 & 0 \\
\hline O39:HNM(1) & eae & FW & 1 & January-14 & 7.2 \\
\hline O40:HNM(1) & eae & FW & 1 & February-14 & 0 \\
\hline O42:H37(1) & eae & FW & 3 & March-13 & 0 \\
\hline $\mathrm{O} 5: \mathrm{H} 40(1)$ & eae & SFm & 2 & February-13 & 0.8 \\
\hline O51:HNM(1) & eae & FW & 2 & October-13 & 22.8 \\
\hline \multirow[t]{4}{*}{ O63:H6(4) } & eae & FW & 1 & November-13 & 15.4 \\
\hline & & FW & 2 & November-13 & 0.1 \\
\hline & & FW & 1 & January-14 & 7.2 \\
\hline & & FW & 3 & October-14 & 0.5 \\
\hline O63:HNM(1) & eae & FW & 3 & October-14 & 0.5 \\
\hline O71:H49(2) & eae & $\operatorname{SFm}(1), \operatorname{SFc}(1)$ & 1 & October-13 & 0.4 \\
\hline O71:HNM(1) & eae & FW & 1 & August-14 & 1.0 \\
\hline O8:H14(1) & eae & FW & 1 & November-13 & 15.4 \\
\hline O85:H31(1) & eae & FW & 1 & October-14 & 8.3 \\
\hline O85:HNM(1) & eae & FW & 1 & August-14 & 1.0 \\
\hline O86:H31(1) & eae & SFC & 2 & August-14 & 26.0 \\
\hline O88:H25(1) & eae & SFm & 3 & September-14 & 0.4 \\
\hline O88:H8(1) & eae & SFo & 3 & August-14 & 26.0 \\
\hline O9:HNM(1) & eae & FW & 2 & November-13 & 0.1 \\
\hline O91:H1O(1) & eae & SFC & 1 & July-14 & 6.5 \\
\hline O98:H56(1) & eae & FW & 1 & December-14 & 0 \\
\hline O98:H8(1) & eae & SFm & 1 & November-13 & 15.4 \\
\hline \multirow[t]{2}{*}{ O98:HNM(2) } & eae & SW & 1 & February-14 & 0 \\
\hline & & FW & 1 & March-14 & 0 \\
\hline O98:HNT(1) & eae & FW & 1 & December-14 & 0 \\
\hline ONT:H2(1) & eae & FW & 1 & August-13 & 2.8 \\
\hline ONT:H31(1) & eae & FW & 1 & October-14 & 8.3 \\
\hline ONT:H34(1) & eae & FW & 3 & December-14 & 10.6 \\
\hline \multirow[t]{6}{*}{ ONT:H6(6) } & eae & FW & 1 & September-13 & 1.0 \\
\hline & & FW & 1 & August-14 & 1.0 \\
\hline & & FW & 3 & September-14 & 0.4 \\
\hline & & FW & 3 & October-14 & 0.5 \\
\hline & & SFm & 2 & December-14 & 0 \\
\hline & & SW & 1 & December-14 & 10.6 \\
\hline \multirow[t]{2}{*}{ ONT:H8(2) } & eae & FW & 1 & April-14 & 0 \\
\hline & & FW & 1 & August-14 & 1 \\
\hline \multirow[t]{2}{*}{ ONT:HNT(2) } & eae & SW & 1 & November-14 & 24.0 \\
\hline & & FW & 3 & October-14 & 10.6 \\
\hline O28:HNM(1) & eae+ehxA & FW & 1 & June-14 & 0.2 \\
\hline O145:H28(2) & eae+ehxA & $\operatorname{SFm}(1), \operatorname{SFc}(1)$ & 2 & June-13 & 6.1 \\
\hline 0177:H11(1) & eae+ehxA & FW & 2 & July-14 & 1.4 \\
\hline \multirow[t]{2}{*}{ O26:H11(6) } & eae(5), eae+ehxA(1) & FW & 2 & August-13 & 0.7 \\
\hline & & $\mathrm{FW}(3), \operatorname{SFm}(1), \operatorname{SFc}(1)$ & 1 & November-13 & 15.4 \\
\hline \multirow[t]{3}{*}{ O103:H2(3) } & eae(2), eae+ehxA(1) & FW & 2 & February-13 & 0.8 \\
\hline & & FW & 2 & June-13 & 6.1 \\
\hline & & FW & 1 & November-13 & 15.4 \\
\hline \multirow[t]{2}{*}{ O153:H2(3) } & eae(2), eae+ehxA(2) & $\mathrm{SFm}(1), \mathrm{FW}(1)$ & $2(1), 3(1)$ & March-14 & 0.1 \\
\hline & & SFC & 2 & July-14 & 1.4 \\
\hline
\end{tabular}

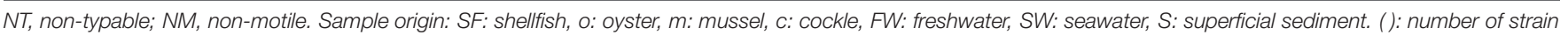

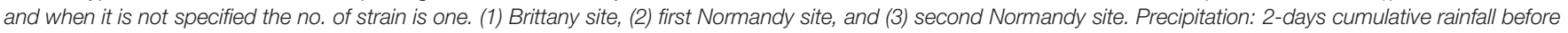
sampling date. 
TABLE 5 | Distribution of phylogroup A, B1, B2, and D among STEC and EPEC strains isolated in the three French shellfish-harvesting sites from the Eastern English Channel coastal area and their watersheds.

\begin{tabular}{|c|c|c|c|c|c|}
\hline Phylogroup & Total & $A(\%)$ & B1 (\%) & B2 (\%) & D (\%) \\
\hline \multicolumn{6}{|l|}{ Site 1} \\
\hline No. STEC strains (\%) ${ }^{a}$ & 12 & $2(16.7)$ & 4 (33.3) & 0 & $6(50.0)$ \\
\hline No. EPEC strains $(\%)^{b}$ & 47 & $13(27.7)$ & $13(27.7)$ & $19(40.4)$ & $2(4.4)$ \\
\hline \multicolumn{6}{|l|}{ Site 2} \\
\hline No. STEC strains (\%)a & 7 & $3(42.9)$ & $3(42.9)$ & $1(14.2)$ & 0 \\
\hline No. EPEC strains $(\%)^{b}$ & 23 & $2(8.7)$ & $13(56.5)$ & $5(21.7)$ & $3(13.0)$ \\
\hline \multicolumn{6}{|l|}{ Site 3} \\
\hline No. STEC strains (\%) ${ }^{\mathrm{a}}$ & 9 & $6(66.7)$ & 3 (33.3) & 0 & 0 \\
\hline No. EPEC strains $(\%)^{b}$ & 19 & $1(5.3)$ & $8(42.1)$ & $10(52.6)$ & 0 \\
\hline \multicolumn{6}{|l|}{ Total of the three sites } \\
\hline No. STEC strains $(\%)^{c}$ & 28 & $11(39.3)$ & $10(35.7)$ & 1 (3.6) & $6(21.4)$ \\
\hline No. EPEC strains (\%) & 89 & $16(18.0)$ & $34(38.2)$ & $34(38.2)$ & $5(5.7)$ \\
\hline
\end{tabular}

a Percentage calculated based on the total no. of STEC strains isolated from each site. ${ }^{\mathrm{b}}$ Percentage calculated based on the total no. of EPEC strains isolated from each site. 'Percentage calculated based on the total no. of STEC and EPEC strains isolated from the three sites.

identified within the STEC strains and contained one or two individual isolates each.

Fifty-seven serotypes were identified among the EPEC strains. Eleven strains belonged to the highly pathogenic serotypes: O26:H11 $(n=6), \mathrm{O} 103: \mathrm{H} 2(n=3)$, and O145:H28 $(n=2)$. The remaining EPEC strains belong to a large diversity of serotypes listed in Table 4.

It should be noted that some serotypes were isolated at different months and in different types of samples. For example, the nine strains of serotype O100:HNM st $x 2^{+}$were isolated from seven shellfish batches ( $n=7$; oyster, mussel, and common cockle batches), from one freshwater $(n=1)$ and from one surface sediment sample $(n=1)$. Three O154:H31 stx $1^{+}$and their immotile form were isolated from two shellfish batches ( $n=2$; oyster and mussel batches) and from one freshwater sample $(n=1)$. The EPEC serotypes, O108:H21 $(n=3)$, O113:H6 $(n=4), \mathrm{O} 15: \mathrm{H} 2(n=2), \mathrm{O} 153: \mathrm{H} 2(n=3), \mathrm{O} 23: \mathrm{H} 8(n=2)$, O26:H11 $(n=6)$, and O71:H49/HNM $(n=3)$ were all isolated from shellfish batches and also from freshwater samples (Table 4).

The same serotypes were sometimes isolated from geographically independent sites. For example, serotypes O103:H2, O125:H6, and O26:H11 were isolated from sites 1 and 2 and serotypes O113:H6, O137:H6, and O179:H31 from sites 1 and 3. Finally, the O63:H6 and ONT:H6 serotypes were isolated from all the three sites (Table 4).

\section{PFGE and MLST Profiles}

The genetic relatedness of 26 STEC and 79 EPEC strains was investigated by PFGE and MLST analysis (Supplementary Figure S2). Seventy-nine distinguishable PFGE patterns (PT) and 46 distinguishable sequence types (STs) were obtained. Seven other STs (seven strains, one STEC and six EPEC) were obtained but have not as yet been described. These results demonstrate a high level of genetic diversity among the strains isolated. The highest diversity was observed for the EPEC strains, which represented $8.1 \%$ of the PTs identified (64/79) and $71.7 \%$ of the STs $(33 / 46)$.

The STEC serotype O100:HNM $(n=9)$ presented identical PT (D) and ST (ST933; Figure 1A) despite of their three specificities: isolated (a) from oyster, mussel, and common cockle batches, freshwater, and superficial sediment samples, (b) from the sites 2 and 3, (c) during the sampling campaigns of May 2013, June 2013, March 2014, and June 2014. With regards to the major serotypes (Figure 1B), the six EPEC O26:H11 strains presented three additional PTs (i.e., L, BV, and AL) and two STs (i.e., ST29 and ST48) isolated from mussel and common cockle batches and freshwater samples. One of those belonging to the ST29 was isolated from the same mussel batch from which the STEC O26:H11 belonging to the ST21 was isolated. A unique PT (I) was observed for the two EPEC O145:H28 (ST not yet described), isolated from mussel and common cockle batches and sampled during the same campaign (June 2013). Both O103:H2 isolated during two different months (i.e., June 2013 and November 2013) had distinguishable PTs (i.e., M and N) and STs (i.e., ST1146 and ST343). Additionally, identical PTs and STs were found among the other STEC and EPEC strains isolated from different types of sample (i.e., shellfish vs. freshwater) or between shellfish batches (i.e., mussel vs. common cockle) and between freshwater samples, often from samples taken from the same sites on the same date (e.g., O153:H2, O108:H21 serotypes; Supplementary Figure S2).

\section{Biofilm Formation}

Biofilm formation by a subset of 13 EPEC and nine STEC strains was evaluated at 18 and $30^{\circ} \mathrm{C}$ on plastic surface. At both temperatures, strains varied in their ability to form biofilm (OD590 $=0.03$ for the lowest, OD590 = 1.9 for the highest). In general, a large number of strains were strongly to moderately adherent and more strains formed a biofilm at 18 than at $30^{\circ} \mathrm{C}$ (Figure 2). Indeed, 11 of the 22 strains formed strong biofilms [serotypes O2:H32, O149:H1, ONT:H11, O91:H21, O185:H28, O26:H11 $(n=2)$, O145:H28 $(n=1)$, O103:H2 $(n=3)]$, six formed medium biofilms [serotypes O26:H11 $(n=3), \mathrm{O} 145: \mathrm{H} 28$ $(n=2)$ and O125:H6] and five formed weak biofilms or no biofilm at all [serotypes O100:HNM, O154:H31, O15:H16, and O26:H11 $(n=2)]$. At $30^{\circ} \mathrm{C}, 11$ strains formed strong biofilms [serotypes O2:H32, O149:H1, ONT:H11, O91:H21, O185:H28, O145:H28 $(n=3)$, O103:H2 $(n=2)$ and O125:H6] but 
A

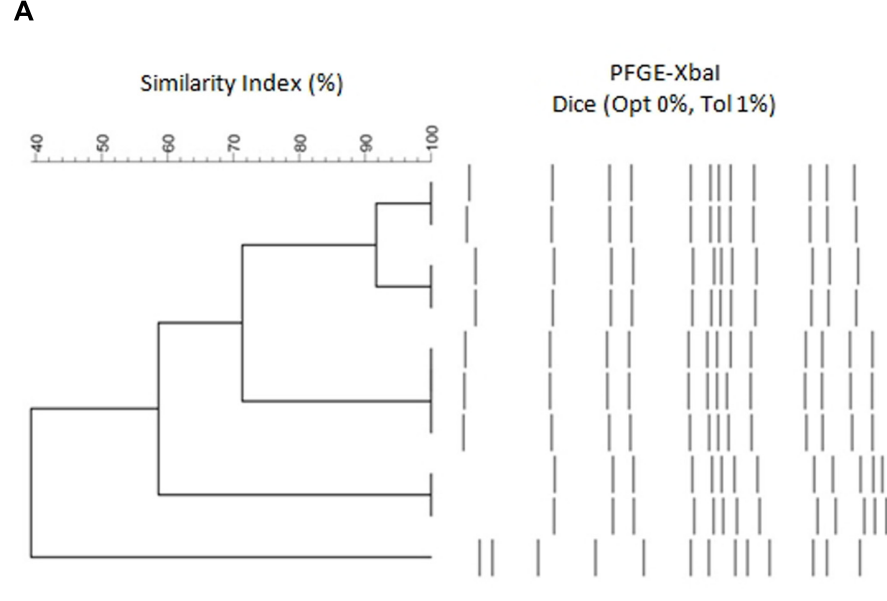

B
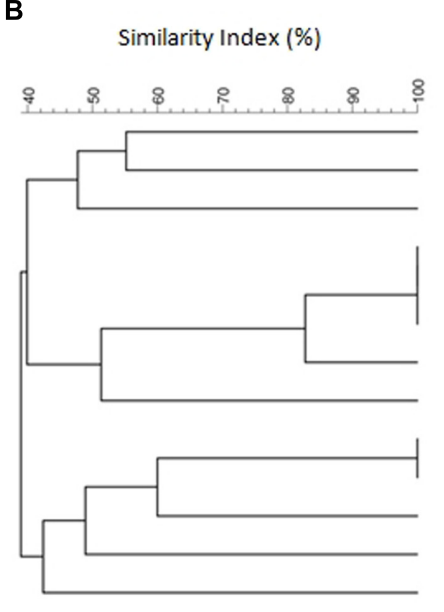

PFGE-Xbal Dice (Opt $0 \%$, Tol $1 \%)$

\begin{tabular}{|c|c|c|c|c|c|c|c|}
\hline$\frac{\mathscr{a}}{\stackrel{0}{E}}$ & $\stackrel{\oplus}{ \pm}$ & 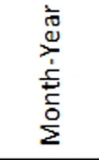 & 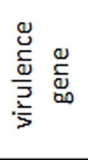 & 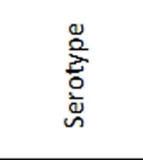 & $\begin{array}{l}\frac{0}{3} \\
0 \\
\frac{0}{0} \\
\frac{0}{2} \\
\frac{1}{2}\end{array}$ & เ & $\hbar$ \\
\hline SFm & 3 & Jun-13 & st $\times 2$ & 0100:HNM & A & D & 993 \\
\hline $\mathrm{S}$ & 3 & Jun-13 & $s t \times 2$ & 0100:HNM & A & D & 993 \\
\hline SFm & 3 & May-13 & stx2 & 0100:HNM & A & D & 993 \\
\hline SFc & 2 & May-13 & st $\times 2$ & 0100:HNM & A & D & 993 \\
\hline SFm & 2 & May-13 & st $\times 2$ & 0100:HNM & A & D & 993 \\
\hline FW & 3 & May-13 & st $\times 2$ & 0100:HNM & A & D & 993 \\
\hline SFo & 3 & May-13 & st $\times 2$ & 0100:HNM & A & D & 993 \\
\hline SFm & 2 & Mar-14 & st $\times 2$ & 0100:HNM & A & D & 993 \\
\hline SFo & 3 & Jun-14 & st $\times 2$ & 0100:HNM & A & D & 993 \\
\hline $\mathrm{FW}$ & 1 & Nov-13 & eae & 0125:H6 & B2 & $\mathrm{J}$ & 583 \\
\hline
\end{tabular}

\section{岌}

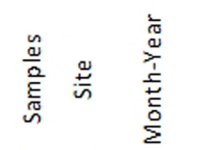

eae

FW 11 Nov-13

FW 1 Nov-13

FW 1 Nov-13

SFm 1 Nov-13

FW 1 Nov-13

FW 1 Nov-13

FW 2 Aug-13

FW 2 Jun-13

SFC 2 Jun-13

SFm 2 Jun-13

FW 3 May-13

SFm 1 Nov-13

FW $\quad 1 \quad$ Feb-14 eae

eae-ehxA

eae

eoe

eae

eae

eoe-ehxA

eae-ehxA

eae-ehxA

stx1-stx2-ehxA-soo

stx1-eoe-ehxA

eae

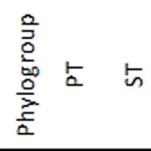

026:H11 B1 BV 29

0103:H2 A M 1146

026:H11 A AL 48

026:H11 B1 L 29

026:H11 B1 L 29

026:H11 B1 L 29

026:H11 B1 L 29

0103:H2 B1 N 343

0145:H28 D I nd

0145:H28 D I nd

O91:H21 B1 T 442

026:H11 B1 AK 21

0103:HNM A AJ 3747

FIGURE 1 | Focused dendograms of Xbal PFGE patterns (PTs), characteristics and Sequence Types (STs) of 9 STEC 0100:HNM (A) and the 13 major serotypes (B) isolated from freshwater (FW), shellfish (SF) [oyster (o), mussel (m), or cockle (c)] and superficial sediment (S), from the Brittany site (1) and the two Normandy sites (2 and 3). The similarity of PFGE profiles was compared and dendogram was created with the Bionumerics software 7.5 (Applied Maths, Belgium), using the band-based Dice unweighted-pair group method, using average linkages (UPGMA), based on 1\% position tolerance. NT: non-typable, NM: non-motile, nd: not determined.

fewer $(n=2)$ were able to form a medium biofilm (O26:H11 and $\mathrm{O} 145: \mathrm{H} 28)$ and nine formed a weak biofilm [serotypes O100:HNM, O15:H16, O154:H31, O26:H11 $(n=6)$; Figure 2]. Interestingly, all O26:H11 strains formed significantly (MannWhitney test) more biofilm $(p<0.05)$ at $18^{\circ} \mathrm{C}$ than at $30^{\circ} \mathrm{C}$.

\section{Antibiotic Resistance}

Antimicrobial susceptibility testing based on the disk diffusion method was performed on 38 EPEC strains and on all STEC strains $(n=28)$. Most of the analyzed STEC and EPEC strains [i.e., $85.7 \%(24 / 28)$ and $73.7 \%$ (28/38), respectively] were sensitive toward all 16 used antibiotics. Only four STEC strains were resistant to one antibiotic (i.e., Doxycyclin). With regard to EPEC, $7.9 \%(3 / 38)$ of strains [i.e., serotypes O63:H6, O71:H49, and O98:H8] were resistant to one antibiotic (i.e., Doxycyclin or Imipenem) and $13.2 \%(5 / 38)$ of strains were resistant to two antibiotics (i.e., Cefotaxim/Cefoxitin, O63:H6 or Doxycyclin/Bactrim, O26:H11 or Ticarcillin/Amoxicillin, $\mathrm{O} 26: \mathrm{H} 11, n=3)$. One of the O26:H11 serotype was resistant to three antibiotics (i.e., Gentamycin/Ticarcillin/Amoxicillin). Finally, the O2:H45 serotype $(n=1)$ was resistant to four antibiotics (i.e., Cefalotin/Imipenem/Cefotaxim/Cefoxitin).

\section{DISCUSSION}

To our knowledge, this study is the first to focus on the detection and characterization of environmental STEC and EPEC strains from shellfish-harvesting areas and their upstream watershed. Overall, among the environmental samples analyzed $(n=505)$, very few STEC $(0.2 \%, n=28)$ or EPEC $(0.7 \%, n=89)$ strains were obtained from the E. coli that were isolated $(n=12,016)$ and in comparison with the number of shellfish, water or surface sediment samples that were found to be positive for stx and 


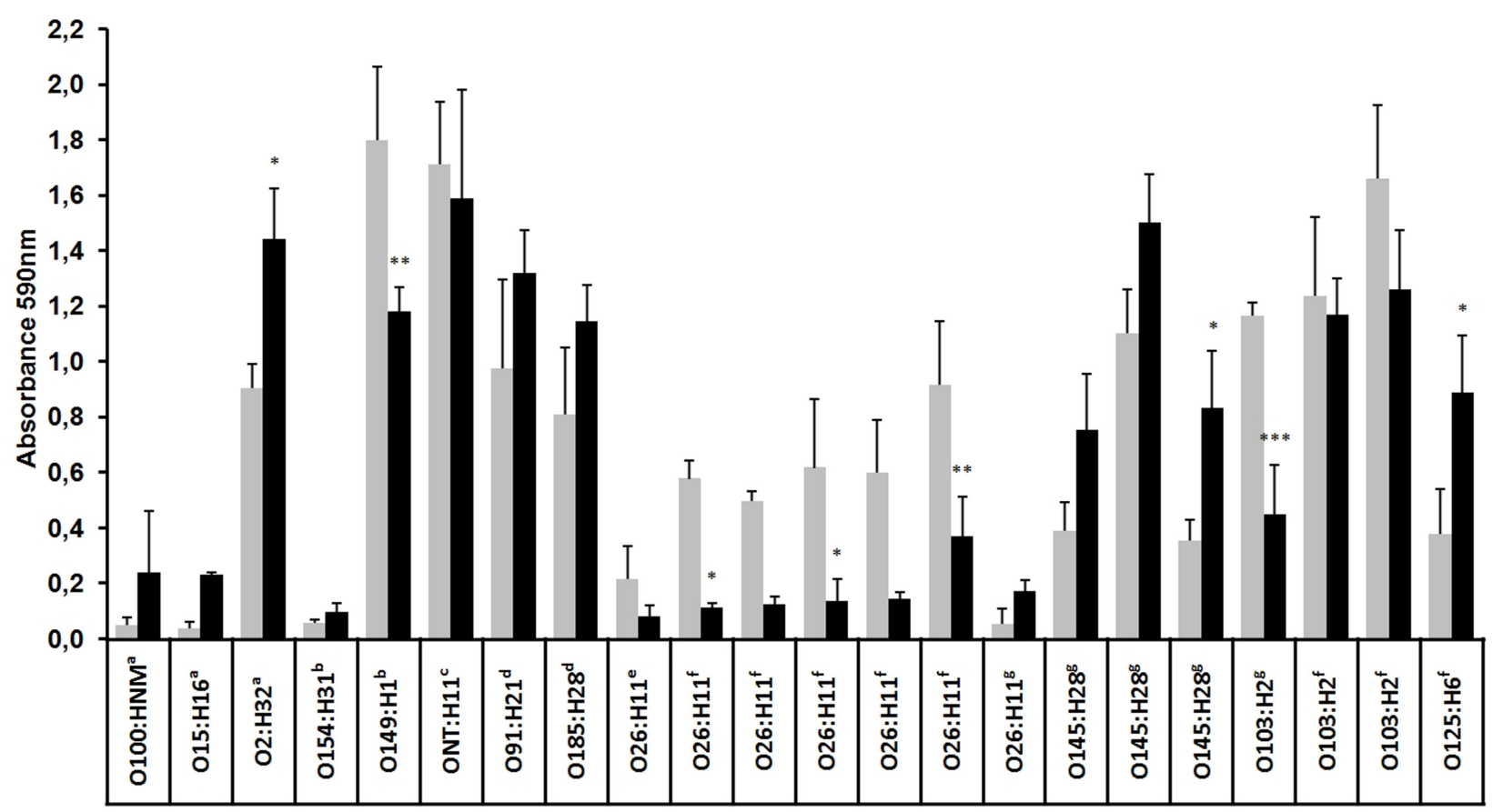

FIGURE 2 | Biofilm formation by EPEC and STEC strains at low and high temperatures. Biofilms were formed on polystyrene in M9 medium supplemented with glucose $(0.4 \% \mathrm{wt} / \mathrm{vol})$ at $18^{\circ} \mathrm{C}$ (gray bars) or $30^{\circ} \mathrm{C}$ (dark bars) for $24 \mathrm{~h}$ and were stained with crystal violet, and the absorbance at $590 \mathrm{~nm}$ was measured. The results are the average of at least three biological replicates and the error bar represent the standard error. The results for the static biofilms formed at 18 and $30^{\circ} \mathrm{C}$ were compared using two-way analysis of variance (ANOVA) followed by a Bonferroni post hoc comparison. ${ }^{*} p<0.05 ;{ }^{* *} p<0.01{ }^{* * *} p<0.001$. ${ }^{a}$ st $x 2^{+},{ }^{b}$ st $x 1^{+}$, ${ }^{\mathrm{c}} \mathrm{st} \times 1^{+}$-st $x 2^{+},{ }^{\mathrm{d}}$ st $x 1^{+}$-st $x 2^{+}-\mathrm{eh} \times \mathrm{A}^{+}-\mathrm{saa}{ }^{+},{ }^{\mathrm{e}} \mathrm{st} \times 1^{+}-\mathrm{eae}{ }^{+},{ }^{\mathrm{f}} \mathrm{eae}{ }^{+},{ }^{\mathrm{g}} \mathrm{eae}{ }^{+}-\mathrm{eh} \times \mathrm{A}^{+}$

eae genes $(54.1 \%, 273 / 505)$. The higher proportion of EPEC than STEC strains isolated from these environmental samples is in agreement with the results obtained in previous studies (Hamilton et al., 2010; Chandran and Mazumder, 2015). For example, only 3.6\% EPEC and no STEC were detected among the 24,493 E. coli isolated from seawater collected in Santa Catalina Island, CA, USA (Hamilton et al., 2010). Conversely, more STEC strains (6.2\%) than EPEC strains (1.8\%) were isolated from water samples from the Yeongsan river basin in South Korea $(n=3,480$ E. coli; Jang et al., 2014). The low level of isolation of STEC or EPEC vs. the high frequency of detection of genetic markers in the analyzed samples has also been observed in various studies focusing on cattle feces, food, and samples from the environment (Miyagi et al., 2001; Bai et al., 2015; Bibbal et al., 2015). The low level of isolation of STEC vs. the high detection of stx genes in the environmental samples could be explained by the presence of free st $x$-encoding bacteriophages in the environment (MartinezCastillo et al., 2013) and the presence of viable but non-culturable or dead bacteria as a result of the stressful conditions (sunlight, salinity, oligotrophy, predation, etc.) in riverine and especially coastal environments (Gourmelon et al., 1997, for review Rozen and Belkin, 2001). The difficulties of isolating these bacteria from environmental samples containing a significant background flora could also contribute to this low recovery of strains (Pradel et al., 2000; Gourmelon et al., 2006).

The strains isolated in coastal areas of Brittany (site 1) and Normandy (sites 2 and 3) present a high diversity of serotypes as has been previously reported for environmental samples in California or Spain (García-Aljaro et al., 2005; Cooley et al., 2014). A subset of the serotypes isolated in the present study was previously isolated from humans, animals, or the environment. Serotypes such as O8:H14, O26:H11, O76:H19, O91:H21, O103:H2/HNM, O145:H28, and O154:H31 have previously been associated with human infections (Beutin and Fach, 2014). In addition, STEC serotypes O130:H11 and O154:HNM were detected in healthy cattle and waters (Hornitzky et al., 2002), the serotype O157:H16 in dogs, humans, and in the environment (Feng et al., 2012), and the serotype O149:H1 in shellfish (Gourmelon et al., 2006). The STEC O100:HNM was previously detected in swine fecal samples, wild boar feces, and drinking water contaminated by waste water (García-Aljaro et al., 2005; Lienemann et al., 2011; Mora et al., 2012).

In addition, a high genetic diversity among the 105 genotyped strains was observed, with 79 PFGE patterns and 46 distinguishable sequence types in agreement with the high genetic diversity observed by PFGE in other studies for STEC and EPEC strains (Bibbal et al., 2015; Singh et al., 2015). In this study, PFGE was found to be more discriminatory than MLST as previously described for bacteria such as Salmonella isolated in Californian coastal waters (Walters et al., 2013). For example, seven strains belonging to ST10 (seven different serotypes) were further discriminated into seven distinct PTs ( $, A G, A H, A W, X$, $\mathrm{G}$, and $\mathrm{Y}$ ). The identification of numerous PTs and STs highlights the potential presence of different strains in a same sample and 
the presence of genetic diversity between strains belonging to the same serotype (e.g., E. coli O26:H11 ST21 and ST29 in the same mussel batch).

The non-detection of E. coli from the O157:H7 serotype in the shellfish, water and surface sediment samples investigated (from February 2013 to February 2014 ( $n=282$, Balière et al., 2015) is in agreement with the low detection or absence of E. coli O157 in shellfish and environmental water previously observed (Miyagi et al., 2001; Manna et al., 2008).

Several EPEC strains belonging to the highly pathogenic serogroups (i.e., O26, O103, and O145) were also isolated from some of the shellfish batches or freshwater samples that were analyzed. The STEC O26:H11 ST21 found in a mussel batch was shown to be implicated in STEC infections and has been detected in cattle in Europe (Zweifel et al., 2013).

The EPEC O26:H11 ST29 isolated in this study can be strains with no previous contact with stx-bacteriophages or bacteria that have lost the stx-bacteriophage either during their passage from their original source to water or shellfish or during their isolation steps. The presence of these bacteria in coastal environments could present a risk to human health as these EPEC could be lysogenized by stx1- or stx2-converting bacteriophages, which are present in the same environment and could become STEC of the highly pathogenic serotypes. In fact, Bielaszewska et al. (2007) demonstrated that STEC O26 strains can lose their stxbacteriophages and become EPEC O26, and conversely EPEC O26 can be lysogenized by stx1- or stx2-bacteriophages and become STEC O26. Even if the conversion of strains was found to occur in the digestive tract of different animals (Toth et al., 2003) and in various food matrices (Imamovic et al., 2009), the environment could also provide the conditions for conversion of strains. However, the potential conversion of E. coli strains in the environment still needs to be evaluated in more details (Dumke et al., 2006). Interestingly, Solheim et al. (2013) have demonstrated the conversion of an E. coli strain (serotype O103:H25) by bacteriophages in a biofilm at $37^{\circ} \mathrm{C}$, but also at $20^{\circ} \mathrm{C}$.

In addition, another STEC strain isolated in a freshwater sample could present a potential human risk. Indeed, an O91:H21 E. coli was found to belong to ST442, a sequence type that had previously been isolated from adult patients in Germany with symptoms that ranged from diarrhea to hemolytic uremic syndrome (Mellmann et al., 2009).

The majority of strains isolated in this study would present low virulence as most of the isolated strains (87.2\%) possessed only one of the five virulence genes (stx1, stx2, eae, ehxA, or saa); i.e., $70.1 \%$ of the strains carried the eae gene, $7.7 \%$ st $x 1$ and $11.1 \%$ stx2). The STEC O26:H11 was the only STEC isolate to carry the eae gene. These results are in agreement with previous studies describing STEC strains isolated from the environment (García-Aljaro et al., 2005) with the exception of the analysis of water samples from a Californian central coast agricultural region where Cooley et al. (2014) showed that the majority of STEC strains isolated contained stx1, stx2, and eae genes. The low level of isolation of STEC strains carrying the saa gene encoding another adherence factor, the STEC autoagglutinating adhesion, or the gene ehxA encoding enterohemolysin A was in agreement with the results obtained from water samples in Spain by García-Aljaro et al. (2005).

Most of the STEC strains in this study were classified into the A, B1, and D phylogroups. Phylogroups A and B1 were also the main phylogroups of environmental STEC strains isolated by García-Aljaro et al. (2005) in Spain. In the Yeongsan river basin of South Korea, STEC strains isolated belonged mainly to phylogroup D and to a lesser extent to phylogroups A, B1, and B2 (Jang et al., 2014). In Brittany and Normandy, overall, the EPEC strains belonged mainly to phylogroups B1 and B2 and to a lesser extent to A and D. EPEC strains isolated from water samples in South Korea belonged mainly to the B2 phylogroups (Jang et al., 2014). The frequent isolation of E. coli from B1 phylogroup in the present study is in agreement with recent data showing that environmentally persistent $E$. coli belong mainly to the B1 phylogroup (Berthe et al., 2013).

Phenotypic differences in the ability to form biofilms among tested strains underline the genetic diversity of STEC or EPEC strains. Our study demonstrates that more than half of the tested strains $(17 / 22)$ were able to form biofilms on polystyrene at 18 or $30^{\circ} \mathrm{C}$, and most of these strains were able to form strong biofilm at $18^{\circ} \mathrm{C}$, a temperature close to marine environment condition. A similar result had been observed previously when E. coli $\mathrm{K} 12$ biofilm was grown at low temperature (WhiteZiegler et al., 2008). It has been shown that low temperatures $\left(<30^{\circ} \mathrm{C}\right)$ promote the expression of genes associated with biofilm development, including genes involved in curli ( $\operatorname{csg} A$ and $m \operatorname{lr} A$ ) or cellulose (yaiC) production (Olsen et al., 1989; Arnqvist et al., 1992; White-Ziegler et al., 2008). Interestingly, although O26:H11 strains formed weaker biofilms than other strains, they formed significantly stronger biofilms at $18^{\circ} \mathrm{C}$ than at $30^{\circ} \mathrm{C}$. Also, all but one $\mathrm{O} 26: \mathrm{H} 11$ strains were negative for $\mathrm{pgaA}$, a gene coding for the export of poly- $N$-acetyl-D-glucosamine (PGA) that promotes biofilm formation (Itoh et al., 2008; data not shown). In addition, pgaA sequence is also absent in the sequenced genomes of STEC O26 strains available in GenBank. In conclusion, the ability of strains to form a biofilm might contribute to their persistence in coastal environments.

This study highlights the presence of a specific geographic distribution of some of the STEC and EPEC serotypes and a persistence of some of these serotypes in the coastal environments from Brittany and Normandy investigated in this study. The isolation of the serotype O100:HNM positive for stx2 (PT D and ST993), at different dates (over a period of 1 year), in shellfish, waters and surface sediments from both sites in Normandy (sites 2 and 3), but its absence in Brittany (site 1), highlights potential specific contamination sources in these region and the higher persistence of some of these specific strains. This had previously been shown in water samples from California for O157 strains isolated up to 19 months apart by Cooley et al. (2014). The various livestock breeding in the three watersheds, i.e., mainly swine, poultry and bovine in Brittany and sheep, bovine and swine in Normandy, could explain differences in strain detection at specific sites. A potential explanation of the frequent isolation of the STEC O100:HNM is the high carriage of this E. coli strain in the animals in the upstream watersheds. Bibbal et al. (2015) have identified farms harboring STEC bovine carriers, highlighting the 
fact that STEC of a given serotype could be carried by several animals belonging to the same farm. A probable prediction of the presence of these STEC strains in the coastal environment is their re-introduction to the water and consequently to shellfish from animal reservoirs, which enables persistence at high titer for months (Cooley et al., 2014). Another explanation could be that they are present in surface sediments in which a better persistence could occur and then they are re-introduced to the water and then filtered and accumulated by shellfish. The evaluation of the persistence of STEC and EPEC (especially those isolated several times in this study, i.e., E. coli $\mathrm{O} 100$ and E. coli O26) in freshwaters and seawaters and in shellfish needs to be studied to better understand their frequent detection in such shellfishharvesting areas. Several studies have been carried out to evaluate the persistence of STEC in water or superficial sediments and these have shown that some E. coli strains are able to persist in the environment for periods of a few days to several months (Fremaux et al., 2010) and that the persistence could be variable according to the serotypes (Ma et al., 2014).

This study critically evaluated the nature of STEC and EPEC strains present in coastal environments. Knowledge of strains circulating in the environment is crucial to the investigation of potential new STEC serotypes and their human health risk. These results confirm that the environment is a reservoir for these strains. The presence of both EPEC strains and stx-converting bacteriophages in the same samples could lead to new pathogenic E. coli.

The risk of a human infection by STEC caused by shellfish consumption seems to be limited for two reasons. First, a depuration step or relaying step has to be performed before

\section{REFERENCES}

Anonymous (2004). Regulation (EC) No 854/2004 of the European parliament and of the council of 29 April 2004 laying down specific rules for the organisation of official controls on products of animal origin intended for human consumption. Official J. Euro. Union L139, 83-127.

Arnqvist, A., Olsen, A., Pfeifer, J., Russell, D. G., and Normark, S. (1992). The Crl protein activates cryptic genes for curli formation and fibronectin binding in Escherichia coli HB101. Mol. Microbiol. 6, 2443-2452. doi: 10.1111/j.13652958.1992.tb01420.x

Bai, X., Wang, H., Xin, Y., Wei, R., Tang, X., Zhao, A., et al. (2015). Prevalence and characteristics of Shiga toxin-producing Escherichia coli isolated from retail raw meats in China. Int. J. Food Microbiol. 200, 31-38. doi: 10.1016/j.ijfoodmicro.2015.01.018

Balière, C., Rincé, A., Thevenot, D., and Gourmelon, M. (2015). Successful detection of pathogenic Shiga-toxin-producing Escherichia coli in shellfish, environmental waters and sediment using the ISO/TS-13136 method. Lett. Appl. Microbiol. 60, 315-320. doi: 10.1111/lam.12386

Bennani, M., Badri, S., Baibai, T., Oubrim, N., Hassar, M., Cohen, N., et al. (2011). First detection of Shiga toxin-producing Escherichia coli in shellfish and coastal environments of Morocco. Appl. Biochem. Biotechnol. 165, 290-299. doi: 10.1007/s12010-011-9251-x

Berthe, T., Ratajczak, M., Clermont, O., Denamur, E., and Petit, F. (2013). Evidence for coexistence of distinct Escherichia coli populations in various aquatic environments and their survival in estuary water. Appl. Environ. Microbiol. 79, 4684-4693. doi: 10.1128/AEM.00698-13

Beutin, L., and Fach, P. (2014). Detection of Shiga toxin-producing Escherichia coli from nonhuman sources and strain typing. Microbiol. Spectr. 2, EHEC-0001-2013. doi: 10.1128/microbiolspec.EHEC0001-2013 shellfish from category B and C areas, respectively, reach market. Secondly, STEC were present in only a few samples and the majority of STEC strains lacked genes associated with high human virulence, such as eae, and few of the STEC isolated in this study have previously been shown to be involved in human infections.

\section{ACKNOWLEDGMENTS}

This work was funded by the European Regional Development Fund Interreg IVA Programme, as part of the collaborative project RiskManche. The thesis of $\mathrm{CB}$ was supported by a grant from Ifremer and the Agence de l'Eau Loire-Bretagne. We thank Clémence Balière from the University of Caen and Céline Courroux from Hôpital Robert-Debré, for their participation in the sampling and technical assistance and Dominique HervioHeath (Ifremer) and Huw Taylor (University of Brighton, UK) for their critical review of the manuscript. Work in the LRECUSC-laboratory was financed by the grant CN2012/303 from Consellería de Cultura, Educación e Ordenación Universitaria (Xunta de Galicia) and The European Regional Development Fund, ERDF).

\section{SUPPLEMENTARY MATERIAL}

The Supplementary Material for this article can be found online at: http://journal.frontiersin.org/article/10.3389/fmicb. 2015.01356

Bibbal, D., Loukiadis, E., Kerouredan, M., Ferre, F., Dilasser, F., de Garam, C. P., et al. (2015). Prevalence of carriage of Shiga toxin-producing Escherichia coli serotypes O157:H7, O26:H11, O103:H2, O111:H8, and O145:H28 among slaughtered adult cattle in France. Appl. Environ. Microbiol. 81, 1397-1405. doi: 10.1128/aem.03315-14

Bidet, P., Mariani-Kurkdjian, P., Grimont, F., Brahimi, N., Courroux, C., Grimont, P., et al. (2005). Characterization of Escherichia coli O157:H7 isolates causing haemolytic uraemic syndrome in France. J. Med. Microbiol. 54, 71-75. doi: 10.1099/jmm.0.45841-0

Bielaszewska, M., Prager, R., Köck, R., Mellmann, A., Zhang, W., Tschäpe, H., et al. (2007). Shiga toxin gene loss and transfer in vitro and in vivo during enterohemorrhagic Escherichia coli O26 infection in humans. Appl. Environ. Microbiol. 73, 3144-3150. doi: 10.1128/AEM.02937-06

Blanco, M., Blanco, J. E., Mora, A., Rey, J., Alonso, J. M., Hermoso, M., et al. (2003). Serotypes, virulence genes, and intimin types of Shiga toxin (verotoxin)producing Escherichia coli isolates from healthy sheep in Spain. J. Clin. Microbiol. 41, 1351-1356. doi: 10.1128/JCM.41.4.1351-1356.2003

Chandran, A., and Mazumder, A. (2013). Prevalence of diarrhea-associated virulence genes and genetic diversity in Escherichia coli isolates from fecal material of various animal hosts. Appl. Environ. Microbiol. 79, 7371-7380. doi: 10.1128/AEM.02653-13

Chandran, A., and Mazumder, A. (2015). Pathogenic potential, genetic diversity, and population structure of Escherichia coli strains isolated from a forestdominated watershed (Comox Lake) in British Columbia, Canada. Appl. Environ. Microbiol. 81, 1779-1789. doi: 10.1128/aem.03738-14

Clermont, O., Bonacorsi, S., and Bingen, E. (2000). Rapid and simple determination of the Escherichia coli phylogenetic group. Appl. Environ. Microbiol. 66, 4555-4558. doi: 10.1128/AEM.66.10.4555-4558.2000

Cooley, M. B., Quiñones, B., Oryang, D., Mandrell, R. E., and Gorski, L. (2014). Prevalence of shiga toxin producing Escherichia coli, Salmonella enterica, 
and Listeria monocytogenes at public access watershed sites in a California Central Coast agricultural region. Front. Cell. Infect. Microbiol. 4:30. doi: 10.3389/fcimb. 2014.00030

Costa, R. A. (2013). Escherichia coli in seafood: a brief overview. Adv. Biosci. Biotechnol. 4, 450-454. doi: 10.4236/abb.2013.43A060

Croxen, M. A., Law, R. J., Scholz, R., Keeney, K. M., Wlodarska, M., and Finlay, B. B. (2013). Recent advances in understanding enteric pathogenic Escherichia coli. Clin. Microbiol. Rev. 26, 822-880. doi: 10.1128/CMR.00022-13

Dumke, R., Schröter-Bobsin, U., Jacobs, E., and Röske, I. (2006). Detection of phages carrying the Shiga toxin 1 and 2 genes in waste water and river water samples. Lett. Appl. Microbiol. 42, 48-53. doi: 10.1111/j.1472765X.2005.01809.x

EFSA (2013). EFSA Panel on Biological Hazards (BIOHAZ); scientific opinion on VTEC-seropathotype and scientific criteria regarding pathogenicity assessment. EFSA J. 11, 3138. doi: 10.2903/j.efsa.2013.3138

Feng, P. C. H., Keys, C., Lacher, D. W., Beutin, L., Bentancor, A., Heuvelink, A., et al. (2012). Clonal relations of atypical enteropathogenic Escherichia coli O157:H16 strains isolated from various sources from several countries. FEMS Microbiol. Lett. 337, 126-131. doi: 10.1111/1574-6968.12017

Fremaux, B., Prigent-Combaret, C., Beutin, L., Gleizal, A., Trevisan, D., Quetin, P., et al. (2010). Survival and spread of Shiga toxin-producing Escherichia coli in alpine pasture grasslands. J. Appl. Microbiol. 108, 1332-1343. doi: 10.1111/j.1365-2672.2009.04527.x

García-Aljaro, C., Muniesa, M., Blanco, J. E., Blanco, M., Blanco, J., Jofre, J., et al. (2005). Characterization of Shiga toxin-producing Escherichia coli isolated from aquatic environments. FEMS Microbiol. Lett. 246, 55-65. doi: 10.1016/j.femsle.2005.03.038

Gourmelon, M., Montet, M., Lozach, S., Le Mennec, C., Pommepuy, M., Beutin, L., et al. (2006). First isolation of Shiga toxin 1d producing Escherichia coli variant strains in shellfish from coastal areas in France. J. Appl. Microbiol. 100, 85-97. doi: 10.1111/j.1365-2672.2005.02753.x

Gourmelon, M., Touati, D., Pommepuy, M., and Cormier, M. (1997). Survival of Escherichia coli exposed to visible light in seawater: analysis of rpoS-dependent effects. Can. J. Microbiol. 43, 1036-1043. doi: 10.1139/m97-148

Guinée, P. A. M., Jansen, H. W., Wadstrom, T., and Sellwood, R. (1981). "Escherichia coli associated with neonatal diarrhoea in piglets and calves," in Laboratory Diagnosis in Neonatal Calf and Pig Diarrhoea: Current Topics in Veterinary and Animal Science, Vol. 13, eds P. W. De Leeww and P. A. M. Guinée (Hague: Martinus Nijhoff), 126-162.

Hamilton, M. J., Hadi, A. Z., Griffith, J. F., Ishii, S., and Sadowsky, M. J. (2010). Large scale analysis of virulence genes in Escherichia coli strains isolated from Avalon Bay, CA. Water Res. 44, 5463-5473. doi: 10.1016/j.watres.2010.06.058

Hornitzky, M. A., Vanselow, B. A., Walker, K., Bettelheim, K. A., Corney, B., Gill, P., et al. (2002). Virulence properties and serotypes of Shiga toxin-producing Escherichia coli from healthy Australian cattle. Appl. Environ. Microbiol. 68, 6439-6445. doi: 10.1128/AEM.68.12.6439-6445.2002

Imamovic, L., Jofre, J., Schmidt, H., Serra-Moreno, R., and Muniesa, M. (2009). Phage-mediated Shiga toxin 2 gene transfer in food and water. Appl. Environ. Microbiol. 75, 1764-1768. doi: 10.1128/AEM.02273-08

Itoh, Y., Rice, J. D., Goller, C., Pannuri, A., Taylor, J., Meisner, J., et al. (2008). Roles of pgaABCD genes in synthesis, modification, and export of the Escherichia coli biofilm adhesin poly-beta-1,6-N-acetyl-D-glucosamine. J. Bacteriol. 190, 3670-3680. doi: 10.1128/JB.01920-07

Iwamoto, M., Ayers, T., Mahon, B. E., and Swerdlow, D. L. (2010). Epidemiology of seafood-associated infections in the United States. Clin. Microbiol. Rev. 23, 399-411. doi: 10.1128/CMR.00059-09

Jang, J., Di, D. Y., Lee, A., Unno, T., Sadowsky, M. J., and Hur, H. G. (2014). Seasonal and genotypic changes in Escherichia coli phylogenetic groups in the Yeongsan River basin of South Korea. PLoS ONE 9:e100585. doi: 10.1371/journal.pone.0100585

Jiang, C., An, T., Wang, S., Wang, G., Si, W., Tu, Y., et al. (2015). Role of the ehxA gene from Escherichia coli serotype O82 in hemolysis, biofilm formation, and in vivo virulence. Can. J. Microbiol. 61, 335-341. doi: 10.1139/cjm-2014-0824

Levine, M. M., and Edelman, R. (1984). Enteropathogenic Escherichia coli of classic serotypes associated with infant diarrhea: epidemiology and pathogenesis. Epidemiol. Rev. 6, 31-51.

Lienemann, T., Pitkanen, T., Antikainen, J., Molsa, E., Miettinen, I., Haukka, K., et al. (2011). Shiga Toxin-Producing Escherichia coli O100:H-: $\operatorname{stx}(2 \mathrm{e})$ in
Drinking Water Contaminated by Waste Water in Finland. Curr. Microbiol. 62, 1239-1244. doi: 10.1007/s00284-010-9832-x

Ma, J., Ibekwe, A. M., Crowley, D. E., and Yang, C.-H. (2014). Persistence of Escherichia coli $\mathrm{O} 157$ and non-O157 strains in agricultural soils. Sci. Total Environ. 490, 822-829. doi: 10.1016/j.scitotenv.2014.05.069

Manna, S. K., Das, R., and Manna, C. (2008). Microbiological quality of finfish and shellfish with special reference to Shiga toxin-producing Escherichia coli O157. J. Food. Sci. 73, M283-M286. doi: 10.1111/j.1750-3841.2008.00815.x

Martinez-Castillo, A., Quirós, P., Navarro, F., Miró, E., and Muniesa, M. (2013). Shiga toxin 2-encoding bacteriophages in human fecal samples from healthy individuals. Appl. Environ. Microbiol. 79, 4862-4868. doi: 10.1128/AEM. 01158-13

McDaniel, T. K., Jarvis, K. G., Donnenberg, M. S., and Kaper, J. B. (1995). A genetic locus of enterocyte effacement conserved among diverse enterobacterial pathogens. Proc. Natl. Acad. Sci. U.S.A. 92, 1664-1668. doi: $10.1073 /$ pnas. 92.5 .1664

Mellmann, A., Fruth, A., Friedrich, A. W., Wieler, L. H., Harmsen, D., Werber, D., et al. (2009). Phylogeny and disease association of Shiga toxinproducing Escherichia coli O91. Emerg. Infect. Dis. 15, 1474-1477. doi: 10.3201/eid1509.090161

Miyagi, K., Omura, K., Ogawa, A., Hanafusa, M., Nakano, Y., Morimatsu, S., et al. (2001). Survival of Shiga toxin-producing Escherichia coli O157 in marine water and frequent detection of the Shiga toxin gene in marine water samples from an estuary port. Epidemiol. Infect. 126, 129-133.

Moldoveanu, A. M. (2012). Environmental factors influences on bacterial biofilms formation. Ann. RSCB XVII, 118-126.

Mora, A., López, C., Dhabi, G., López-Beceiro, A. M., Fidalgo, L. E., Díaz, E. A., et al. (2012). Seropathotypes, phylogroups, Stx subtypes, and intimin types of wildlife-carried, Shiga toxin-producing Escherichia coli strains with the same characteristics as human-pathogenic isolates. Appl. Environ. Microbiol. 78, 2578-2585. doi: 10.1128/AEM.07520-11

Muniesa, M., Jofre, J., García-Aljaro, C., and Blanch, A. R. (2006). Occurrence of Escherichia coli O157:H7 and other enterohemorrhagic Escherichia coli in the environment. Environ. Sci. Technol. 40, 7141-7149. doi: 10.1021/es060927k

Nataro, J. P., and Kaper, J. B. (1998). Diarrheagenic Escherichia coli. Clin. Microbiol. Rev. 11, 142-201.

Nielsen, E. M., and Andersen, M. T. (2003). Detection and characterization of verocytotoxin-producing Escherichia coli by automated 5' nuclease PCR assay. J. Clin. Microbiol. 41, 2884-2893. doi: 10.1128/JCM.41.7.2884-2893.2003

O’Brien, A. D., Newland, J. W., Miller, S. F., Holmes, R. K., Smith, H. W., and Formal, S. B. (1984). Shiga-like toxin-converting phages from Escherichia coli strains that cause hemorrhagic colitis or infantile diarrhea. Science 226, 694-696. doi: 10.1126/science.6387911

Olsen, A., Jonsson, A., and Normark, S. (1989). Fibronectin binding mediated by a novel class of surface organelles on Escherichia coli. Nature 338, 652-655. doi: 10.1038/338652a0

Paton, A. W., and Paton, J. C. (2002). Direct detection and characterization of Shiga toxigenic Escherichia coli by Multiplex PCR for stx1, stx2, eae, ehxA, and saa. J. Clin. Microbiol. 40, 271-274. doi: 10.1128/JCM.40.1.271-274.2002

Paton, A. W., Srimanote, P., Woodrow, M. C., and Paton, J. C. (2001). Characterization of saa, a novel autoagglutinating adhesin produced by locus of enterocyte effacement-negative shiga-toxigenic Escherichia coli strains that are virulent for humans. Infect. Immun. 69, 6999-7009. doi: 10.1128/IAI.69.11.6999-7009.2001

Paton, J. C., and Paton, A. W. (1998). Pathogenesis and diagnosis of Shiga toxin-producing Escherichia coli infections. Clin. Microbiol. Rev. 11, $450-479$.

Perelle, S., Dilasser, F., Grout, J., and Fach, P. (2007). Screening food raw materials for the presence of the world's most frequent clinical cases of Shiga toxinencoding Escherichia coli O26, O103, O111, O145 and O157. Int. J. Food Microbiol. 113, 284-288. doi: 10.1016/j.ijfoodmicro.2006.08.014

Potasman, I., Paz, A., and Odeh, M. (2002). Infectious outbreaks associated with bivalve shellfish consumption: a worldwide perspective. Clin. Infect. Dis. 35, 921-928. doi: 10.1086/342330

Pradel, N., Livrelli, V., Champs, C. D., Palcoux, J.-B., Reynaud, A., Scheutz, F., et al. (2000). Prevalence and characterization of Shiga toxin-producing Escherichia coli isolated from cattle, food, and children during a one-year prospective study in France. J. Clin. Microbiol. 38, 1023-1031. 
Rozen, Y., and Belkin, S. (2001). Survival of enteric bacteria in seawater. FEMS Microbiol. Rev. 25, 513-529. doi: 10.1111/j.1574-6976.2001.tb00589.x

Russo, T. A., and Johnson, J. R. (2000). Proposal for a new inclusive designation for extraintestinal pathogenic isolates of Escherichia coli: ExPEC. J. Infect. Dis. 181, 1753-1754. doi: 10.1086/315418

Scheutz, F., Teel, L. D., Beutin, L., Piérard, D., Buvens, G., Karch, H., et al. (2012). Multicenter evaluation of a sequence-based protocol for subtyping Shiga toxins and standardizing Stx nomenclature. J. Clin. Microbiol. 50, 2951-2963. doi: 10.1128/JCM.00860-12

Singh, P., Sha, Q., Lacher, D. W., Del Valle, J., Mosci, R. E., Moore, J. A., et al. (2015). Characterization of enteropathogenic and Shiga toxin-producing Escherichia coli in cattle and deer in a shared agroecosystem. Front. Cell. Infect. Microbiol. 5:29. doi: 10.3389/fcimb.2015.00029

Solheim, H. T., Sekse, C., Urdahl, A. M., Wasteson, Y., and Nesse, L. L. (2013). Biofilm as an environment for dissemination of stx genes by transduction. Appl. Environ. Microbiol. 79, 896-900. doi: 10.1128/AEM.03512-12

Toth, I., Schmidt, H., Dow, M., Malik, A., Oswald, E., and Nagy, B. (2003). Transduction of porcine enteropathogenic Escherichia coli with a derivative of a shiga toxin 2-encoding bacteriophage in a porcine ligated ileal loop system. Appl. Environ. Microbiol. 69, 7242-7247. doi: 10.1128/AEM.69.12.72427247.2003

Touchon, M., Hoede, C., Tenaillon, O., Barbe, V., Baeriswyl, S., Bidet, P., et al. (2009). Organised genome dynamics in the Escherichia coli species results in highly diverse adaptive paths. PLoS Genet. 5:e1000344. doi: 10.1371/journal.pgen.1000344

Tremblay, Y. D., Vogeleer, P., Jacques, M., and Harel, J. (2015). High-throughput microfluidic method to study biofilm formation and host-pathogen interactions in pathogenic Escherichia coli. Appl. Environ. Microbiol. 81, 2827-2840. doi: 10.1128/AEM.04208-14

Usda Food Safety and Inspection Service (2011). Risk Profile for Pathogenic Non-O157 Shiga Toxin-Producing Escherichia coli (non-O157STEC). USDA Food Safety and Inspection Service, Washington, DC. Available at: http://www.fsis.usda.gov/pdf/non_o157_stec_risk_profile.pdf
Vogeleer, P., Tremblay, Y. D., Mafu, A. A., Jacques, M., and Harel, J. (2014). Life on the outside: role of biofilms in environmental persistence of Shiga-toxin producing Escherichia coli. Front. Microbiol. 5:317. doi: 10.3389/fmicb.2014.00317

Walters, S. P., González-Escalona, N., Son, I., Melka, D. C., Sassoubre, L. M., and Boehm, A. B. (2013). Salmonella enterica diversity in central Californian coastal waterways. Appl. Environ. Microbiol. 19, 4199-4209. doi: 10.1128/AEM. 00930-13

White-Ziegler, C. A., Um, S., Perez, N. M., Berns, A. L., Malhowski, A. J., and Young, S. (2008). Low temperature (23 degrees C) increases expression of biofilm-, cold-shock- and RpoS-dependent genes in Escherichia coli K-12. Microbiology 154, 148-166. doi: 10.1099/mic.0.2007/012021-0

WHO (1987). Program for Control of Diarrhoeal Diseases. Manual for Laboratory Investigation of Acute Enteric Infections. Geneva: World Health Organization.

Wirth, T., Falush, D., Lan, R., Colles, F., Mensa, P., Wieler, L. H., et al. (2006). Sex and virulence in Escherichia coli: an evolutionary perspective. Mol. Microbiol. 60, 1136-1151. doi: 10.1111/j.1365-2958.2006.05172.x

Zweifel, C., Cernela, N., and Stephan, R. (2013). Detection of the emerging Shiga toxin-producing Escherichia coli O26:H11/H- sequence type 29 (ST29) clone in human patients and healthy cattle in Switzerland. Appl. Environ. Microbiol. 79, 5411-5413. doi: 10.1128/AEM.01728-13

Conflict of Interest Statement: The authors declare that the research was conducted in the absence of any commercial or financial relationships that could be construed as a potential conflict of interest.

Copyright (c) 2015 Balière, Rincé, Blanco, Dahbi, Harel, Vogeleer, Giard, MarianiKurkdjian and Gourmelon. This is an open-access article distributed under the terms of the Creative Commons Attribution License (CC BY). The use, distribution or reproduction in other forums is permitted, provided the original author(s) or licensor are credited and that the original publication in this journal is cited, in accordance with accepted academic practice. No use, distribution or reproduction is permitted which does not comply with these terms. 